San Jose State University

SJSU ScholarWorks

Master's Theses

Master's Theses and Graduate Research

1999

\title{
Cultural dimensions of corporate branding in the United States and Japan
}

Kiyomi Nagakura

San Jose State University

Follow this and additional works at: https://scholarworks.sjsu.edu/etd_theses

\section{Recommended Citation}

Nagakura, Kiyomi, "Cultural dimensions of corporate branding in the United States and Japan" (1999).

Master's Theses. 1830.

DOI: https://doi.org/10.31979/etd.kuhe-m49n

https://scholarworks.sjsu.edu/etd_theses/1830

This Thesis is brought to you for free and open access by the Master's Theses and Graduate Research at SJSU ScholarWorks. It has been accepted for inclusion in Master's Theses by an authorized administrator of SJSU ScholarWorks. For more information, please contact scholarworks@sjsu.edu. 


\section{INFORMATION TO USERS}

This manuscript has been reproduced from the microfilm master. UMI films the text directly from the original or copy submitted. Thus, some thesis and dissertation copies are in typewriter face, while others may be from any type of computer printer.

The quality of this reproduction is dependent upon the quality of the copy submitted. Broken or indistinct print, colored or poor quality illustrations and photographs, print bleedthrough, substandard margins, and improper alignment can adversely affect reproduction.

In the unlikely event that the author did not send UMI a complete manuscript and there are missing pages, these will be noted. Also, if unauthorized copyright material had to be removed, a note will indicate the deletion.

Oversize materials (e.g., maps, drawings, charts) are reproduced by sectioning the original, beginning at the upper left-hand corner and continuing from left to right in equal sections with small overlaps. Each original is also photographed in one exposure and is included in reduced form at the back of the book.

Photographs included in the original manuscript have been reproduced xerographically in this copy. Higher quality 6" $\times 9$ " black and white photographic prints are available for any photographs or illustrations appearing in this copy for an additional charge. Contact UMI directly to order.

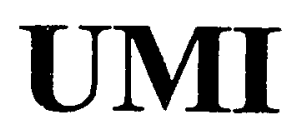

A Bell \& Howell Information Company 



\title{
CULTURAL DIMENSIONS OF CORPORATE BRANDING IN THE UNITED STATES AND JAPAN
}

\author{
A Thesis \\ Presented to \\ San Jose State University \\ In Partial Fulfillment \\ of the Requirements for the Degree \\ Master of Science
}

The Faculty of the School of Journalism and Mass Communications

by

Kiyomi Nagakura

May 1999 
UMI Number: 1394542

Copyright 1999 by Nagakura, Riyomi

All rights reserved.

\section{UMI Microform 1394542}

Copyright 1999, by UMI Company. All rights reserved.

This microform edition is protected against unauthorized copying under Title 17, United States Code.

\section{UMI}

300 North Zeeb Road

Ann Arbor, MI 48103 
(C) 1999

Kiyomi Nagakura

ALL RIGHTS RESERVED 
APPROVED FOR THE SCHOOL OF JOURNALISM AND MASS COMMUNICATIONS
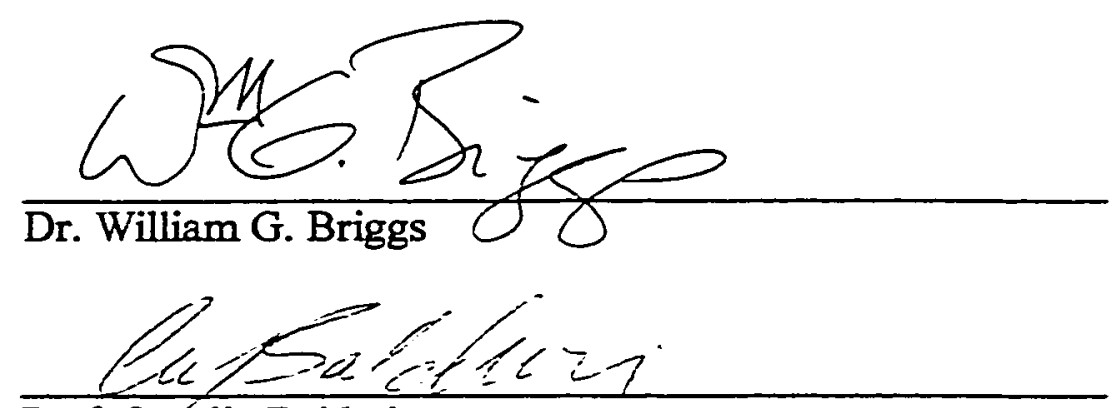

Prof. Cecelia Baldwin

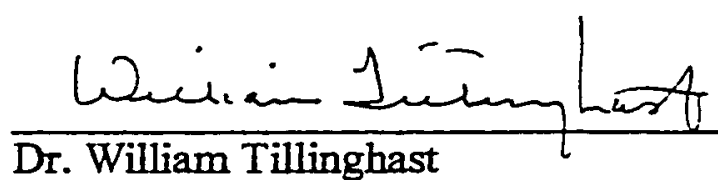

Dr. William Tillinghast

APPROVED FOR THE UNIVERSITY

William Fish 


\title{
ABSTRACT \\ CULTURAL DIMENSIONS OF CORPORATE BRANDING \\ IN THE UNITED STATES AND JAPAN
}

\author{
by Kiyomi Nagakura
}

This study explored whether there are differences between the United States and Japan in corporate advertising as it relates to corporate branding. It considered the question, "What differences are there between U.S. and Japanese companies in their use of corporate advertising for the purpose of corporate branding?"

The method of research was content analysis. The research variables were identified according to cross-cultural theories, mainly Hofstede's cultural dimensions. The researcher employed semiotics to analyze visual elements in magazine corporate advertisements.

The study found that cultural influences appeared randomly in corporate advertisements in both the United States and Japan. The differences that appeared to be significant included the use of visual elements and copy, and the information content about a company's history, company size, and technology or design breakthroughs. 
To all my advisors,

who provided insightful guidance.

to my family,

who offered continuing support.

and to my husband,

who gave me tremendous encouragement 


\section{CHAPTER}

I. INTRODUCTION AND RATIONALE 1

Purpose of Study 2

Applicable Research $\quad 2$

Overview of Methods 3

II. LITERATURE REVIEW 5

Corporate Branding in the International Markets 5

Corporate Branding 5

$\begin{array}{ll}\text { The International Market } & 7\end{array}$

$\begin{array}{ll}\text { Culture } & 10\end{array}$

$\begin{array}{lr}\text { Overview of Culture } & 10\end{array}$

$\begin{array}{lll}\text { Cultural Dimensions } & 11\end{array}$

$\begin{array}{ll}\text { The Levels of Analysis } & 17\end{array}$

$\begin{array}{ll}\text { Societal Constraints } & 17\end{array}$

$\begin{array}{ll}\text { Organizational Constraints } & 22\end{array}$

$\begin{array}{ll}\text { Individuals } & 27\end{array}$

$\begin{array}{ll}\text { Visual Analysis: Semiotics } & 28\end{array}$ 
III. METHOD 31

Study Design 31

The Content Analysis Method 31

Overview of the Sample 31

Data Collection $\quad 32$

$\begin{array}{ll}\text { Research Variables } & 32\end{array}$

$\begin{array}{ll}\text { Sample Selection } & 37\end{array}$

$\begin{array}{ll}\text { Sampling } & 38\end{array}$

Description of the Sample $\quad 39$

Data Analysis $\quad 39$

$\begin{array}{ll}\text { Coding and Reliability } & 39\end{array}$

$\begin{array}{ll}\text { Hypotheses } & 40\end{array}$

$\begin{array}{ll}\text { Generalizability } & 42\end{array}$

IV. FINDINGS AND DISCUSSIONS 43

$\begin{array}{ll}\text { Findings } & 43\end{array}$

Overview of Results $\quad 43$

Low-context vs. High-context Cultures 45

Individualism vs. Collectivism $\quad 47$

Power Distance $\quad 48$

$\begin{array}{ll}\text { Uncertainty Avoidance } & 50\end{array}$

$\begin{array}{ll}\text { Long-term Orientation } & 50\end{array}$ 
$\begin{array}{ll}\text { Signs in Pictures } & 52\end{array}$

Discussion $\quad 53$

Implications of the Results $\quad 53$

$\begin{array}{ll}\text { Additional Findings } & 58\end{array}$

V. SUMMARY AND CONCLUSIONS 65

$\begin{array}{ll}\text { Summary } & 65\end{array}$

$\begin{array}{ll}\text { Overview of the Study } & 65\end{array}$

$\begin{array}{ll}\text { Main Findings } & 65\end{array}$

$\begin{array}{ll}\text { Conclusion } & 66\end{array}$

$\begin{array}{ll}\text { Conclusion } & 66\end{array}$

$\begin{array}{ll}\text { Contribution to Theory and Practice } & 67\end{array}$

$\begin{array}{ll}\text { Limitation of Research } & 68\end{array}$

Direction for Future Research 69

$\begin{array}{ll}\text { VI. REFERENCES } & 70\end{array}$

$\begin{array}{ll}\text { VII. APPENDIX } & 75\end{array}$ 


\section{LIST OF TABLES}

Table 1

Research Variables for Informational Content

Table 2

Test Results of the Hypotheses

Table 3

Distribution of Corporate Advertisements by the Portion of Visual Elements

Table 4

Distribution of Corporate Advertisements by the Portion of Copy

Table 5

Distribution of Corporate Advertisements by Information Contents about Company Size

Table 6

Distribution of Corporate Advertisements by Information Contents about Company's $\underline{\text { History }}$

Table 7

Distribution of Corporate Advertisements by Type of Endorser

Table 8

Distribution of Corporate Advertisements by Type of Spokesperson

Table 9

Distribution of Corporate Advertisements by Signs: Subjects in Pictures

Table 10

Distribution of Corporate Advertisements by Symbolic Subjects in Pictures

Table 11

Distribution of Corporate Advertisements by the Relationship between Pictures and Headlines 


\section{Introduction and Rationale}

The rapid development of new communication technologies and the lowering of trade barriers have had a dramatic impact on international markets. An emerging term, global village, leaves us with the impression that national boundaries do not exist or are no longer significant.

Existing research suggests that national macro-level influences, such as politics, economics, culture, and mass communication, are linked and can be examined to predict how organizations in different countries perform or operate their businesses. Although American marketing theories and strategies are rather advanced and are used worldwide, they have basically been derived from uniquely American perspectives. When applied elsewhere, these marketing theories and strategies have to be modified, and the impact of differences between the macro-level influences in various countries has to be taken into consideration.

The researcher found the need for further investigation of the differences between macro-level influences on marketing activities in U.S. markets and parallel influences in Japanese markets. Japan is the second largest U.S. export market after Canada (Handy facts, 1998). By understanding the differences, U.S. companies could make their activities more meaningful and effective. To examine the differences, the researcher selected corporate branding as one of the essential marketing communication activities for both countries today. 


\section{Purpose of Study}

This study identified differences between the United States and Japan in corporate advertising as it relates to corporate branding. Corporate advertising refers to advertising that promotes the company rather than its specific products or services (Rossiter \& Percy. 1997). Specifically, the study focused on how U.S. and Japanese companies show their corporate equity as informational content in corporate advertising to practice corporate branding. Through an analysis of corporate advertising in the two countries, this study hoped to answer the question. "What differences are there between U.S. and Japanese companies concerning their use of corporate advertising for corporate branding purposes?"

\section{Applicable Research}

To answer the above question, the researcher explored several approaches in the literature and constructed a theoretical framework for this study. First, the concept of corporate branding was examined, with a focus on integrated marketing communication and corporate advertising. Furthermore, factors influencing market strategies in international markets were identified.

Second, the researcher employed cultural theories to examine differences between the United States and Japan as one of the key uncontrollable variables. Through the examination, research variables for this study were identified. However, corporate branding could be influenced by many other factors, ranging from the micro- to macrolevels. Moreover, cultural influences could appear in different levels such as the levels of organizational constraints and individuals. To give an entire context for corporate 
branding, the researcher also explored other factors on the macro-level, and cultural influences and other factors on the levels of organizational constraints and individuals. primarily focusing on Japan. Through these examinations, the researcher hoped to provide supplementary information about the similarities and dissimilarities between these two countries, convey the impact of these cultural differences. and identify the significance of corporate branding in Japan.

Lastly, this study hoped to analyze visual elements as well as informational content in corporate advertising. By employing semiotics, which is the science of signs. this study tried to identify differences between the United States and Japan in terms of visual communication.

\section{Overview of Methods}

Media content analysis was selected for this study because this method could provide "an indicator of many underlying forces" (Shoemaker \& Reese, 1996, p.27). In other words, the media content analysis method enabled the researcher to analyze how U.S. and Japanese corporate advertising for corporate branding purposes were different.

To create the sample of corporate advertisements, this study used two media-newspapers and magazines--as research publications. The reasons for this were twofold. First, newspapers were suitable because this medium is one of the popular forms for corporate advertising in both the United States and Japan (McLeod \& Kunita, 1994). Thus, newspaper advertisements were used to examine differences between the United States and Japan in terms of informational content. However, newspaper advertisements tend to limit creativity (Rossiter \& Percy, 1997). Therefore, magazine advertisements 
were chosen to analyze visual elements in corporate advertising. The sampling period was the entire year of 1998. 


\section{Literature Review}

Corporate Branding in the International Markets

\section{Corporate Branding}

\section{Corporate Branding in the United States}

The need for corporate branding has become more crucial for many U.S. companies in recent years. Gregory (1997) stated that corporate branding is "a more inclusive and more focused concept than either corporate identity or image" (p. 9).

Branding is designed to establish a strong position in markets through various techniques. It identifies the position, image, values, fondness, and character of a product or company (Burnett \& Moriarty, 1998). Although product branding is still important. corporate branding has risen as one of the major forces in corporate communication activities (Gregory, 1997). Gregory reasoned that it is "difficult for many consumers to separate corporate and product brands in their minds when making purchase decisions" (p. 12). By linking cooperate names with favorable attributes, corporate branding can build a special relationship that would bring good effects to the companies and their products or services.

Gregory (1997) stated that the heart of corporate branding is "a purposeful, market-oriented communications platform across all business units, product and service brands, media and audiences" (p. 10). The range of corporate branding consists of every corporate communication activity, including investor relations, public relations, brand 
advertising, sales and distribution communications. employee communications, corporate identity, and corporate advertising.

\section{Integrated Marketing Communication}

The concept of integrated marketing communication (IMC) is key for accomplishing the goal of corporate branding. IMC has emerged from the need to integrate communication and marketing disciplines in marketing activities (Shultz, Tannenbaum, \& Lauterborn, 1993). Originally, most of the communication and marketing disciplines, such as advertising, public relations, sales promotions. and personal selling, have developed theories and conducted practices in their respective fields. However, these disciplines would work more effectively if they could be integrated to help achieve a specific business goal.

\section{Corporate Advertising}

Among all the communication activities of IMC, advertising is key in terms of corporate branding. As Rossiter and Percy (1997) stated, "Corporate advertising communications in the total activities sense are probably aimed at any audience that has some stake in the company's well-being" (p. 332). They listed the five major target audiences: suppliers, regulators, competitors, employees, and customers. In other words, corporate advertising is the place where a company can express its identity along with its audiences and action objectives.

In Managing brand equity, Aaker (1991) stated that the use of corporate advertising could exercise a positive influence on the value of brand equity. In fact, 
Gregory (1997) found a positive correlation between the level of advertising expenditures and corporate reputations in the Fortune 100 companies.

Corporate advertising is one of the essential marketing communication tools in both the United States and Japan. In the United States, approximately $50 \%$ of all companies employed corporate advertising (Rossiter \& Percy, 1997). With respect to Japan, Koukoku hakusho 1997 [The advertising white paper in Japan] reported that the rate of corporate advertising had been increasing even though Japan was in a recession.

\section{The International Market}

\section{$\underline{\text { International Marketing Communication }}$}

Other factors that do not exist in domestic business do influence the strategy for corporate branding in international markets. Griffin (1993) stated that there are several uncontrollable variables in international markets: political and legal, economic, cultural, competition, infrastructural, and technological variables. All these variables are very significant and often inseparable because they influence and direct one another.

\section{Uncontrollable Variables}

Uncontrollable variables that would influence an entire national characteristic are political and legal, economic, and cultural variables. As in the United States, in Japan the basic principle of political and legal variables is democracy. Likewise, in both countries, capitalism is the basic economic variable.

Are there differences in cultural significance between the United States and Japan? Hofstede (1984b) stated that the degree of cultural integration varies between one 
society and another. Hall and Hall (1987) pointed out that it is much harder to define Americans than the more homogeneous Japanese. They stated that the term Americans has a very broad connotation because of the many individual, regional. ethnic, and cultural differences in the large country. Thus, it can be said that the greater the impact of subcultures, the less impact a national culture has.

Rice (1993) categorized the four major subcultures, which he called "microcultures," as geography, ethnicity, religion, and age. In terms of micro-cultures, Japan can be said to be much more homogeneous than the United States. Many Japanese people are under the impression that the Japanese are single race. However. Japanese people are descended from a number of different Mongoloid groups such as Korean and Chinese (Abecasis-Phillips, 1994). As Hanihara stated, "In Japanese, the concepts of 'nation' and 'race' are often referred to by the same term" (as cited in Oblas, 1995, p. vii). In general, Japanese religious belief might be described as more based on superstition or rituals than on belief. A lot of Japanese people would claim to be non-religious, even though they may practice a variety of religious activities (Hendry, 1995). Hendry concluded that the concept of religion and belief in Japan is completely different from religious notions in the United States.

By considering the relatively weak impact of subcultures in Japan, the researcher hypothesizes that national culture is very significant in the Japanese market. Needless to say, cultural factors cannot explain everything. However, it is important to know that cultural influences in the Japanese market are crucial. 


\section{Globalization vs. Localization}

In the rising debates about whether advertising should be globalized or localized, advocates of localized advertising have recommended cultural adaptation. Harvey (1993) indicated that cultural and societal variables could be used as predictor variables that directly influence the advertising process in foreign markets. In researching the international advertising approaches of American corporations, Kanso (1992) concluded, "Communication is largely determined by cultural conditions" (p. 13). Mueller (1992) also employed cultural values to examine Westernization in Japanese advertising.

\section{Cross-cultural Research}

A significant amount of research has been done in investigating the international marketplace. The representative studies are cross-cultural management studies, international organizational communication studies, and marketing communication as cross-cultures studies (Shuter, 1989). Shuter stated that "public relations and advertising are rich communication activities that could be insightfully examined by intercultural communication researchers" (p. 400).

\section{Advertising as a Mirror of Cultures}

Culture influences advertising. In other words, "content of advertising mirrors a society" (Tse, Belk, \& Zhou, 1989). Cross-cultural advertising studies have been done from many points of view by analyzing advertising elements such as appeal, basic forms, execution, creative strategy, communication style, and execution style or execution details (Mooij, 1997). 


\section{Culture}

\section{Overview of Culture}

Several cultural theories were reviewed. To identify cultural characteristics in the United States and Japan, the notion of culture and cultural dimensions in this study were defined. Through the examination of cultural dimensions, the researcher tried to identify in each dimension distinctive values, appeals, or communication styles, which were used as research variables to code corporate advertising. By counting or measuring to compare the research variables, the researcher determined whether cultural influences appeared in both countries' corporate advertising. However, the researcher also attempted to avoid adopting ambiguous variables that rely heavily on the researcher's opinions and thus lack objectivity.

\section{Cultural Studies}

Originally: the cultural perspectives in mass communication research have been developing as a distinct study differentiated from mainstream communication theories. which have had a more scientific emphasis (McQuail, 1994). The first cultural question for media theory was whether mass culture was made by mass communication. The mass culture studies involved media content, questions of media use, or a view of people as a mass.

\section{Defining Culture}

The term culture has numerous definitions in specific areas. It is said that there are more than 160 scholastic definitions of culture (Negandhi, 1983). The term has a 
wide rage of meanings, from the expression of culture to civilization (Mooij, 1997).

Hofstede (1984b) defined culture as "the interactive aggregate of common characteristics that influence a human group's response to its environment" (p. 21). He explained the stabilizing of cultural patterns in the following way: "Outside influence" imposes on "origins." "Origins" form "societal norms." Finally, "societal norms" lead to "consequences."

Above all, Hofstede (1984b) noted that the center of culture was "societal norms," the value systems of major groups of population. Thus, it is important to distinguish between societal norms and consequences. As the societal norms of the United States and Japan, this study first identified the national cultures of the two countries by using cultural dimension. In the second step, this study determined research variables for the study as the consequences of culture.

\section{Cultural Dimensions}

To compare cultures in different groups, many scholars have employed dimensions of cultures (Mooij, 1997). Mooij suggested that dimensions of culture "can be used as an instrument to make comparisons between cultures and to cluster according to behavioral characteristics" (p. 65). This study examined seven cultural dimensions. They are (1) high-context vs. low-context cultures, (2) individualism and collectivism, (3) power distance, (4) uncertainty avoidance, (5) masculinity and femininity, (6) long-term orientation, and (7) communitarian values.

\section{High-context vs. Low-context Cultures}


Hall and Hall (1987. 1991) argued that using a scale from high-context to lowcontext communication could categorize cultures in the world. context being the information surrounding an event. They defined high-context and low-context communication as the following:

\begin{abstract}
A high context ( $\mathrm{HC}$ ) communication or message is one of which most of the information is already in the person, while very little is in the coded, explicit, transmitted part of the message. A low-context (LC) communication is just the opposite. (Hall and Hall, 1987. p. 8)
\end{abstract}

Hall and Hall (1987) gave some examples to clarify their notion of contexts. Twins who have grown together experience high-context communication. They do not have to explain to each other about their behaviors because they know why they behave in a certain way. Two lawyers in a courtroom during trial experience low-context communication. They need to give and take all kinds of information by using their words. Hall and Hall applied these concepts to nations. They identified the culture of the United States as low context and Japanese culture as high context.

Applying this notion to advertising, high-context advertising can be identified by the use of indirect communication styles, like less copy and more symbols (Mooij, 1997). On the other hand, low-context advertising can be recognized by the use of direct communication using more copy, argumentation, facts, and data than is used by highcontext advertising. Thus, the research variables identified here were the portion of copy, 
the quantity of data. and the number and the portion of visual elements such as pictures. graphic illustrations. company logos, and other images appearing in corporate advertising.

\section{Individualism vs. Collectivism}

Hofstede (1991) found five cultural dimensions that could be used to compare national cultures. The first dimension is "individualism and collectivism." Individualism is "the relationship between the individual and the collectivity which prevails in a given society" (Hofstede, 1984b, p. 148). The individualism index (IDV) indicates whether a country has an individualist or a collectivist culture. The IDV showed the United States as a highly individualistic culture and Japan as a collectivistic culture.

Hofstede (1991) found that there was a correlation between low/high context and IDV. Individualistic cultures tend to be low context and collectivistic cultures tend to be high context. In individualistic and low-context cultures, appeal is based on individual character (Mooij, 1997). In fact, many U.S. companies are identified with the person who is the leader or founder of the company (Hall \& Hall, 1991). On the contrary, appeal in collectivistic and high-context cultures is based on groups of people or anonymous people rather than prominent figures. By taking into account these differences in appeal, the research variables identified here were the information contents about which type of spokesperson within organizations is used in corporate advertising.

\section{Power Distance}

The second cultural dimension is "power distance" (Hofstede, 1984b, 1991). The power distance index (PDI) indicates the extent to which more powerful members can 
determine the behaviors of less powerful members and the extent to which less powerful members can determine their own behavior. Among 39 countries, the United States scored below average in this dimension, ranking $25^{\text {th }}$, and Japan scored above average, ranking $21^{\text {st }}$ (Hofstede. 1984b).

Mooij (1997) applied PDI to people’s acceptance of hierarchy. In a relatively large power-distance country such as Japan, people tend to view a hierarchical structure as natural. For example, large companies are often seen as being at the top in the hierarchical structure. This view confirms the result of Han and Schmitt's research about brand extensions in East Asia (1996). They found that East Asian consumers were more likely to trust that products were high quality if large firms marketed them. Furthermore, dependence is a key element of the relationship between people in a hierarchically structured society (Mooij, 1997). Networks of corporations can be seen as a sign of dependence. Conversely, in a lower power-distance culture country such as the United States, authority has negative connotations and people stress equality in their rights and opportunities.

The degree of acceptance of dependence and hierarchy was the key in this dimension. The research variables identified here were the informational content about the size of the company and its networks.

\section{Uncertainty Avoidance}

The third dimension is "uncertainty avoidance" (Hofstede, 1984b, 1991). The uncertainty avoidance index (UAI) indicates the extent to which people are threatened by uncertainty and ambiguity and attempt to avoid these situations. In this dimension, the 
United States scored low and Japan scored very high, almost double the U.S. score on the UAI.

Stability is the appeal used in advertising in a strong uncertainty-avoidance culture (Mooij, 1997). Mooij described the appeal in advertising in such cultures as the need for explanations, structure, long copy, testing, testimonial by experts, and high regard for technology and design. By reflecting upon these appeals, the researcher identified as variables the informational content about testing, type of endorser, and technoiogy or design breakthroughs.

\section{Masculinity and Femininity}

The fourth dimension is "masculinity" and "femininity" (Hofstede, 1984b, 1991). This dimension reflects the duality of male and female roles in a society. The masculinity index (MAS) indicates the degree of masculinity. In masculine cultures, achievement is defined more in terms of recognition and wealth, which Hofstede called "ego accomplishment." In feminine cultures, achievement is defined more in terms of the quality of human contacts and the living environment, which Hofstede called "social accomplishment."

In this dimension, both the United States and Japan were categorized into the same cluster, masculine societies, and the other cluster being feminine societies. The United States scored above the average and Japan scored the highest on the MAS. Research variables were not identified in this dimension because both countries are in the same cluster and this study tried to identify differences between the two countries. 


\section{Long-term Orientation}

The last dimension identified by Hofstede (1991) is "long-term orientation." This dimension includes the values of Confucian philosophy. Long-term orientation is the extent to which a society demonstrates a future-oriented perspective rather than a conventional short-term perspective. On the long-term index, the United States ranked low and Japan ranked high.

With respect to appeals in corporate advertising, informational content about a company's history that implies its long-term existence would represent an important value in a long-term orientation culture.

\section{Communitarian Values}

Hampden-Turner and Trompenaars (1993) added the dimension of "communitarianism" into Hofstede's five cultural dimensions. They defined communitarianism as "the belief that whole organizations, societies, and economies can learn to act coherently to nurture higher rates of economic development" (p. 164). In this dimension, the United States scored low and Japan scored the highest.

As one of the essential values, Hampden-Turner and Trompenaars (1993) argued that the tendency to consider market shares was significant in a communitarian society. By reflecting upon this value, the researcher identified as a variable the informational content about market shares of companies

\section{$\underline{\text { Summary }}$}

The cultural dimensions of the United States are a low-context, highly individualistic, small power-distance culture, relatively weak uncertainty avoidance, high 
masculinity, and short-term orientation. The cultural dimensions of Japan are a highcontext. highly collective, large power-distance culture, strong uncertainty avoidance, high masculinity, long-term orientation, and communitarianism.

\section{The Levels of Analysis}

Admittedly, this study was limited to the exploration of cultural differences between the United States and Japan appearing in corporate advertising. However. the fact is that corporate branding could be influenced by many other factors, ranging from the micro- to macro-levels. Likewise, cultural influences could appear in the different marketing communication activities.

To give an entire context for corporate branding, the researcher explored other factors on the macro level, the level of societal constraints: economics, politics, and mass communication. Furthermore, the researcher examined cultural influences and the significance of corporate branding on the levels of organizational constraints: advertising and corporate branding, and individuals, primarily focusing on Japan. Through these examinations, the researcher hoped to provide additional information about the similarities and dissimilarities between these two countries.

\section{$\underline{\text { Societal Constraints }}$}

\section{$\underline{\text { Economics }}$}

Both countries share the same basic economic principle, capitalism. However, it is said that the United States and Japan have many differences in their economic objectives and structures, the relationship between business and government, 
shareholding systems, and so forth (Sakakibara, 1993). In fact, there are some distinguishing traits in the Japanese economic system. The first one is a strong relationship between government and industry. Genther (1990) pointed out that this relationship between government and business helped them to be more competitive internationally.

The second trait of the Japanese economic system is Keiretsu, corporate groups of inter-industry and intra-industry companies, which do business together to create a competitive edge. The relationships among these Keiretsu companies have been a major point of contention in U.S. and Japanese trade relations (Kotabe \& Wheiler, 1996). The Keiretsu are considered to be rooted in the vertical and group-oriented structure of Japanese society. This type of vertical integration can also be seen in conglomerates in the United States today. However, as Kotabe and Wheiler pointed out, "Long-term working relationships and resultant strong mutual trust are more likely to emerge in Japan's enterprise groups than in vertically integrated companies in the United States" (p. 103).

\section{$\underline{\text { Politics }}$}

Some scholars have indicated that the U.S. culture is essentially a political one. Stevenson (1994) stated, "The only thing all Americans share is citizenship, the basis of our common political culture" (p. 46). Elazar (1994) stated that the political culture has been a "great integrative force in American life" (p. 309) and has allowed for all kinds of Americans to "preserve those differences deemed worth preserving" (p. 309).

It is important to say that the political system of Japan is different from that of the 
United States. Japan is governed by a parliamentary system and has three branches of government: executive, legislative, and judicial (Morgan \& Morgan. 1991). A prime minister may be seen as a powerful leader, however, "the real political power in Japan lies in the permanent government--the bureaucracy" (p. 33).

The bureaucratic system in Japan suits one characteristic of a large powerdistance and strong uncertainty-avoidance culture. Morgan and Morgan (1991) concluded that the need for a hierarchy supported a permanent bureaucratic system outside of the government in Japan. Similarly, Wilks and Wright (1991) pointed out, "Bureaucratic norms include the necessity for consultation. the importance of smooth working relationships" (p. 25).

\section{$\underline{\text { Mass Communication }}$}

There are many differences between these two countries in terms of the characteristics of journalism. Ishizawa (1996) found that the U.S. news media is more aggressive, contained more criticism, and was more independent than the Japanese news media. On the other hand, he defined that the Japanese news media tend to be conservative and homogeneous in comparison with the U.S. news media. Likewise, Stevenson (1994) characterized the Japanese media as using uniformity of coverage, lack of critical reporting, and pervasive self-censorship.

Ishizawa (1996) came to his conclusion by examining one historical aspect of Japanese newspapers. Three giant organizations dominate the newspaper industry in Japan. In 1952, these three giants stopped using wire services as a result of the high cost. Thus, they have had to use their own resources to cover national-level news. That means 
that they have had to develop and maintain close relationships with resources such as government officials and politicians. Consequently, they have a tendency not to criticize them.

There is another considerable factor, which is the existence of "kisha clubs" (reporters clubs), a unique system in the Japanese newspaper industry (Stevenson, 1994). The 400 kisha clubs are attached to every major government and private institution. Club members, journalists who work for Japanese newspapers, are supposed to agree with government officials and other club members. They are basically controlled or bound by each other concerning what they may or may not report.

Additionally, the mass media in these two countries have different functions and structures. There are many indications that the U.S. media have been heading toward fragmentation. Stevenson (1994) argued that individualism and suspicion of govermment have characterized the U.S. media as the most decentralized media in the world. Wilson and Gutierrez (1995) indicated that the U.S. media was heading toward classifying audiences with an emphasis on marketing and advertising. They stated, "Communication media had moved from the era of attracting the audience masses to targeting the audience classes, from mass communication to class communication" (p. 235).

The present situation of the U.S. media confirms the views of these researchers. The U.S. newspapers are local or regional, except for a few specialized papers such as The Wall Street Journal (Stevenson, 1994). Mass appeal magazines have almost died or been replaced by specialized magazines that have specific readers and advertisers. Radio has also moved to local stations with segmented audiences. Furthermore, many kinds of 
TV programs are now available with the advent of cable televisions and satellite televisions.

In terms of media reach. the relationship between media spending and the number of media outlets suggests that the Japanese media are likely to have a stronger impact than the U.S. media is. In other words, the Japanese have been provided with a relatively controlled or uniform information through their limited media channels.

According to American Demographics, Japan ranked in the highest position and the Linited States was second in the world for per capita media spending in 1996 (Cassino, 1997). In Japan, per capita newspaper circulation is indeed the highest in the world. twice that of the United States and three nation-wide newspapers exist (Stevenson, 1994).

Television may be more pervasive in Japan than in the United States (Stevenson, 1994). The daily television viewing audience in Japan is approximately $94 \%$ (Oblas. 1995). In 1992, the average TV viewing time in Japan was 2.5 hours a day, an hour less than the average time spent by Americans (Lin, 1993, as cited in Alden and Martin, 1995). Howerer, to date the Japanese generally do not have as many options for TV channels as Americans do. Japanese broadcasting consists of one public channel and five private channels (Stevenson, 1994). Cable and satellite televisions have been available, however, they have not become that popular yet in Japan. According to Advertising Age, in 1997, the penetration rate of cable television was $10.3 \%$ and the rate of satellite television was $25 \%$ in Japan (Koranteng, 1998). These figures were rather small compared with $67 \%$ for cable television and $6 \%$ for the satellite television in the United States.

Furthermore, the dominance of Dentsu, one of the largest advertising agencies in 
the world, provides an excellent example of the hierarchical character of the Japanese media (Stevenson. 1994). Dentsu controls one third of Japanese TV advertising, one fifth of newspaper advertising, and one third of magazine advertising. Dentsu also has close ties with the government, major corporations, and the media through its public relations agencies. Thus, Dentsu could influence news coverage. public policy, and media contents.

\section{Organizational Constraints}

\section{Advertising}

A number of advertising studies focusing on the United States and Japan have been conducted from a variety of angles in the last decade (Mooij, 1997). In addition to studying media content, these studies examined a range of factors, from advertising management (Griffin, McArthur, Yamaki, \& Hidalgo, 1998) to creative strategies (Di Benedetto, Tamate, \& Chandran, 1992). Some researchers employed cultural values to explain the differences. However, they have tended to take broad approaches and have not considered potential cultural dissimilarities (Lin \& Salwen, 1995).

\section{Findings from Advertising Research}

By using information cues, Ramaprasad and Hasegawa (1992) found differences between U.S. and Japanese TV commercials in the use of creative strategies. They concluded that U.S. commercials frequently used more comparative and hyperbolic strategies. They stated that the smaller use of comparison by Japanese commercials reflected one Japanese cultural characteristic, "avoiding confrontation." They found that the strategies of Japanese commercial advertisers included using unique selling 
propositions and preemption.

By using timing and counting variables. Miracle, Taylor. and Chang (1992) researched the use of brands, company names, and products in TV commercials. They concluded that almost all the company names in the Japanese commercials were shown. They reasoned that the objective of Japanese advertising was to develop trust between consumers and corporations rather than to try sell directly.

Lin and Salwen (1995) analyzed U.S. and Japanese TV commercials by using informational cues as their research variables. The results demonstrated that U.S. advertisements tended to be more informative than Japanese advertisements.

Alden and Martin (1995) analyzed the characteristics of Japanese TV commercials that used humor. They concluded that the humor structures of Japanese commercials were similar to those of U.S. commercials, but that important contents of commercials in the two countries were dissimilar. They employed Hofstede's cultural dimensions as a part of their hypotheses.

Sengupta (1995) undertook a content analysis of portrayals of women in TV commercials, comparing commercials in the United States with TV commercials in Japan. The author argued that role portrayal of women in advertising reflected cultural attitudes about appropriate roles for women in both countries.

Albers-Miller and Gelb (1996) investigated advertising in business publications from 11 countries, including the United States and Japan. To identify whether differences in advertising reflect cultural dimensions, they employed advertising appeals categorized by Hofstede's cultural dimensions as their research variables. Yet the result 
did not support correlation between advertising appeals and cultural dimensions. Mooij (1997) analyzed why their results did not support their hypotheses and suggested that some appeals might not have been categorized in proper cultural clusters.

McLeod and Kunita (1994) conducted a comparative analysis of the type of corporate advertising in U.S. and Japanese newspapers by using a typology based on advertising objectives. The result of their study showed that the objectives of corporate advertising were different from each other. They concluded that the small number of users of issue advertisements in Japan demonstrated a Japanese policy-making style and face-to-face consensus building.

In sum, these studies basicaily tried to identify the differences between the United States and Japan in terms of advertising styles, strategies, and objectives by using various research variables in both countries. It was also important to investigate what cultural variables reflected these differences, as in Albers-Miller and Gelb's study. However, in considering their results, the researcher arrived at the conclusion that content analysis criteria should be derived from cultural dimensions rather than applying conventional research variables into cultural dimensions.

\section{Corporate Identity in East Asia}

Many companies in East Asia take advantage of companies' positive images to build up their corporate identity. There are three types of corporate identity: monolithic identities, branded identities, and endorsed identities (Schmitt \& Simonson. 1997). Companies that are themselves brands have monolithic identities. Many industrial conglomerates and business service companies are known as this type of corporate 
identity: Companies, which are only known to customers by their product or service brands, have branded identities. Procter \& Gamble's brand-management system represents this type of corporate identity. Endorsed identities are hybrids of monolithic and branded identities. In this type, strong company images provide benefits to their brands and vice versa. For example, "General Electric presented itself to the public as a company with multiple GE-endorsed identities" (Schmitt \& Simonson, 1997, p. 68). Schmitt and Simonson (1997) identified that monolithic and endorsed identities were more common in East Asia than the United States.

\section{Corporate Branding in East Asia}

Han and Schmitt (1997) researched product-category dynamics and corporate identity in product brand extensions among Hong Kong and U.S. consumers. They found that East Asian countries, including Japan. tend to focus on corporate equity when they try to provide product brand extensions. They explained, "In contrast to U.S. firms, Japanese and the East Asian firms are more likely to use corporate advertising that stresses the benefits a company brings to its consumers and society at large" (p. 78). With respect to the product brand extension of U.S. companies, they stated that "U.S. firms, in general, seem to rely primarily on the product-related benefits or images provided by their brands" (p. 78).

However, even some of the brand-driven U.S. firms like Protector and Gamble (P\&G) use a different approach in East Asia (Schmitt \& Simonson, 1997). P\&G has modified its corporate identity from a branded identity to an endorsed identity by changing its advertising and packaging. The company uses its corporate name and the 
logo of $P \& G$ at the end of its commercials in East Asia. Indeed, Schmitt and Pan (1994) reported that almost every TV commercial from this consumer giant ended with a shot of the company's logo in Japan. In East Asia, the $P \& G$ name on its products is displayed in bigger characters than in the small type utilized in the United States (Schmitt \& Simonson, 1997).

\section{Corporate Branding in Japan}

In recent years, corporate branding activities have attracted a great deal of attention in Japan. According to Koukoku hakusho 1997 [The advertising white paper in Japan], the most remarkable trend of Japanese advertising in 1996 was the blend of cooperate advertising and product advertising. Although the term corporate branding was not used, the report stated that a number of Japanese companies have tried to connect their products and corporations together in advertising. In the report, about $60 \%$ of the Japanese companies showed their deep concern for the improvement of corporate images.

In fact, Japanese firms have put emphasis on corporate branding. Han and Schmitt (1997) found that large Japanese firms such as Toyota or Sony tend to try to express their goodwill through the company as a whole. Washington (1997) explained this fact as a result of company efforts to promote the quality of their products. For example, Advertising Age recently reported that "Honda plans to strengthen its corporate brand in the next few years as it attempts to take some of the spotlight off its popular Accord car" (Halliday, 1998, p. s24). Honda has noticed that the public doesn't know the name of Honda as much as it knows the name of the Accord. 


\section{$\underline{\text { Visual Elements in Advertising }}$}

Leong, Ang, and Tham (1996) investigated the effect of pictures, consumer information-processing level, ad meaning, and exposure on brand name recall among Asian consumers. Their findings indicated that better recall was obtained with advertising that contained pictures and words than with word-only advertising.

This finding led to an additional research question. "How different is the use of pictures between U.S. and Japanese corporate advertising?" As major visual elements in advertising, pictures should be examined as well as informational content.

\section{Individuals}

$\underline{\text { Public }}$

Corporation may have a different signification for many Japanese people than it does for most Americans. At one time, many Japanese employees were basically guaranteed lifetime employment and promotion by seniority. In exchange for this lifetime guarantee, many Japanese have great loyalty to their companies. Although the current recession has had some impact on this factor, companies are still a big part of Japanese life.

Hall and Hall (1987) pointed out that in Japan, most employees' social relationships and activities take place within company frameworks. Although it is not mandatory, after-hour socializing is one of the essential elements that strengthen bonds among employees. Furthermore, some companies even provide recreational and vocational facilities or company-subsidized housing to their employees. As Hall and Hall stated, "The company is also a kind of extended family" (p. 67) in Japan. Their view 
confirms one of Hofstede's analyses for collectivist cultures. Hofstede (1984a) indicated that "in Collectivist cultures an integration is necessary between business life and private life" (p. 88).

Hofstede (1984a) pointed out that there are differences between individualistic cultures and collectivistic cultures in the characteristics of the employer-employee relationship. He argued that the relationship between the employer and the employee in individualistic cultures is based on the premise of mutual benefit. On the other hand, the relationship between the employer and employee in collectivistic cultures has a moral component. He stated. "It is felt to be similar to the relationship of a child with its extended family where there are mutual traditional obligations" (p. 87).

In fact, some data indicated that the existence of the corporation was very important to the Japanese public. According to 1993 research concerning consumers' buying decisions, $80 \%$ of the respondents answered that they would care which company made the product or service (Kobayashi, 1998). Furthermore, a 1994 study about corporate images in Japan indicated that $86 \%$ of respondents would buy the product or service if they liked the company. Only $16 \%$ of those who did not like the company answered that they would purchase its product or service. These data show how important corporate images and reputations are to the Japanese public.

\section{Visual Analysis: Semiotics}

To answer the additional research question, "How different is the use of pictures between U.S. and Japanese corporate advertising?" the researcher investigated the meaning of visual elements in advertising. It was important because more symbols are 
used in advertising in collectivistic cultures (Mooij, 1997). To examine the connotation of the use of pictures in advertising, the researcher employed semiotics.

\section{Semiotics}

Semiotics is the science of signs (Berger, 1995). A sign is anything that can be used to stand for something else. "The application of semiological analysis opens the possibility of revealing more of the underlying meaning of a text" (McQuail, 1994). Semiotics is well-suited to cultural studies because "culture is the shared ability to recognize, decode, and produce signs and symbols, so culture also is a combination of semiotic habits" (Mooij, 1997, p. 55).

\section{Semiotics in Advertising Research}

Many scholars have used semiotics in advertising research (Noth, 1990). Noth stated. "Semiotics expands the analytic horizon from the verbal message in the narrower sense to the multiplicity of codes used in persuasive communication" (p. 476). Many scholars have extended the semiotic analysis from the verbal message to the visual and the nonverbal message in advertising.

\section{$\underline{\text { Signs }}$}

Signs are the most fundamental system of semiotics (Berger, 1995). Peirce (1962, as cited in Noth, 1990), one of the founders of semiotics, suggested that there are three types of signs: icons, indexes, and symbols. According to Peirce's theory, icons communicate by resemblance to the object signified; indexes communicate by logical connections to the object rather than a direct resemblance; and symbols connect with no 
logical. representative, or conventional matters.

Berger (1998) explained Peirce`s concept of signs by giving some examples.

Signs in airports are icons because most people, regardless of the language they speak. can understand what the signs mean. As an example of indexical signs, Berger used smoke, which indicates fire. When looking at smoke. most people assume that there is a fire. On the other hand, symbols are something that people have to learn. For example, the cross represents Christianity for most people. Likewise, national flags stand for the countries themselves. However, it would be impossible to figure out their meanings if people have never learned their definitions.

\section{Signs in This Study}

The researcher applied Peirce's concept of signs to analyze subjects in pictures in corporate advertising. Subjects in pictures used mainly in advertising were categorized into the three types of signs: icons, indexes, and symbols. Icons represented direct values of the company, such as its products, employees, and headquarter buildings. Indexes were things having logical connections to the company rather than showing an obvious and direct connection like icons. Symbols were things that stand in no logical connections to the company. 


\section{Method}

\section{Study Design}

\section{The Content Analysis Method}

The appropriate research method for this study was content analysis. Media content analysis provides "an indicator of many other underlying forces" (Shoemaker \& Reese, 1996). According to Babbie (1998), content analysis is "well suited to the study of communication and to answering the classic question of communications research: 'Who says what, to whom. why, how, and with what effect?"' (p. 309)

Media content analysis was chosen because this study tries to answer a "how" question, namely, how U.S. and Japanese corporate advertising for corporate branding purposes are different. As a mirror of cultural dimensions, the contents of corporate advertising should have indications for the study.

\section{Overview of the Sample}

This study analyzed newspaper advertisements as one of the popular media for corporate advertising in both the United States and Japan (McLeod \& Kunita, 1994). Newspapers were the ideal medium for this study in terms of their significance because of the high rate of per capita circulation in Japan.

However, because they do not often use color, newspapers tend to limit creative content (Rossiter \& Percy, 1997). To examine visual elements in advertising, more enhanced visual images should be used in the study. TV advertising was eliminated because of the difficulty in obtaining the needed equipment from Japan. Considering the 
above conditions, mass circulation magazines were selected as a sub-medium only for an analysis of visual elements.

The major measures of the study were based on cultural dimensions. The measuring instrument included informational content defined earlier, the use of copy, and the use of visual elements. In addition, visual analysis using semiotic codes was implemented for pictures in corporate advertising. Through an examination of each advertisement, the researcher kept records by counting the number of informational content, visual elements, and semiotic codes, and by measuring the portion of copy and visual elements.

\section{Data Collection}

\section{$\underline{\text { Research Variables }}$}

The date and size of the advertisement were used as basic recording instruments. The identified research variables that examine informational content were as follows: 
Table 1

Research Variables for Informational Content

\begin{tabular}{ll}
\hline Cultural Dimensions & Research Variables \\
\hline Low-context & (a) The portion ${ }^{2}$ of copy \\
vs. & (b) The quantity of data \\
High-context & (c) The number of visual elements \\
Cultures & (d) The portion ${ }^{\mathrm{c}}$ of visual elements \\
\hline
\end{tabular}

Individualism

(a) Type of spokesperson within organizations

vs. (company leaders. identified employees, groups, anonymous

Collectivism employees, other. unknown, and none)

(a) Company size

Power Distance

(b) Company's networks ${ }^{\mathrm{e}}$

(a) Testing

(b) Type of endorser

Uncertainty Avoidance (experts ${ }^{f}$, high-profiled persons, clients, other, unknown. and none)

(c) Technology or design breakthroughs

Long-term Orientation (a) The number of years since the company was founded

Communitarian Values (a) Company's market shares 
${ }^{a}$ The portion was estimated by taking the shared percentages in an advertisement and classifying it into five clusters: $0 \%, 1 \%-25 \%, 26 \%-50 \%, 51 \%-75 \%, 76 \%-100 \%$. ${ }^{\mathrm{b}}$ This data was regarding a company's business, background, and its products or services. 'Visual elements included pictures, graphic illustrations, company logos, and other imageries: charts, diagrams, renderings, and maps. ${ }^{d}$ Company size was identified through the informational content concerning the number of the company's employees or its branches. 'Company's networks were identified through the informational content concerning the company's business partners or affiliate companies. 'Experts included special authorities such as trade magazines or industry awards.

\section{$\underline{\text { Sub-measure }}$}

Additionally, a sub-measure that classified advertising into specific categories was recorded. This study was designed to test hypothesized values based on cultural dimensions to identify the differences between U.S. and Japanese corporate advertising. However, by breaking down the variables into more detailed clusters, the researcher hoped to provide a deeper analysis rather than simply analyzing the samples as a whole.

The sub-measure used for both the informational content analysis and visual analysis was type of business. The sub-measure was recorded to examine the correlation between research variables determined by cultural dimensions and the sub-measure. Both the data from the sub-measure and the non-classified data were analyzed.

The sub-measure, the type of business, was determined by the characteristics of products or services that a company primarily dealt with and the level of involvement. 
These characteristics were (a) manufacturers of low-involvement consumer products, (b) manufacturers of high-involvement consumer products, (c) manufacturers of industrial products, (d) distributors/retailers, (e) low-involvement consumer services. (f) highinvolvement consumer services, (g) industrial services, (h) other. and (i) unknown.

\section{Visual Analysis}

By employing semiotics, the researcher identified variables for visuai analysis in the early section. Subjects in pictures used mainly in corporate advertising were categorized into the three types of signs: icons, indexes, and symbols. Furthermore, another concept from semiotics helped to analyze the symbols.

Signifier and signified. Saussure (1966) suggested that signs were composed by "signifier" and "signified" (as cited in Berger, 1998). According to Saussure (1915/1960), the "signifier" refers to the physical element, such as image or sound, and the "signified" is the mental concept given by a physical sign (as cited in McQuail, 1994).

Saussure (1966) proposed that there is a different relationship between "signifier" and "signified" for symbols that for other signs (as cited in Berger, 1998). The relationship between "signifier" and "signified" is generally arbitrary, meaning unmotivated or unnatural. However, Saussure argued that symbols were never wholly arbitrary. There is a natural tie between "signifier" and "signified."

The researcher applied Saussure 's concepts of "signifier" and "signified" to the analysis of symbolic subjects in pictures. Identified symbols (signifier) were further analyzed to identify what connotations (signified) they had. However, identifying connotations of symbols was not the main purpose of this study. Hence, the researcher 
only analyzed the symbols that had different characteristics in the United States and Japan.

Sub-measures for visual analysis. In addition to the type of business, five other sub-measures that categorized pictures in advertising were recorded. The categories were used to analyze the relationship between the type of signs in pictures by the above semiotics codes and other factors. The categories of the sub-measures were determined through an observation of corporate advertising. To expore the concept of signifier and signified, it would be useful to examine how symbolic subjects are used in pictures.

The first sub-measure examined the types of subjects in pictures. The subjects in pictures were (a) family, (b) children, (c) adults, (d) the elderly, (e) animals, (f) buildings, (g) nature, (h) foods, (i) machinery; (j) special characters, and (k) other. When subjects were people, the number of people, their gender, and their facial expressions were recorded. The categories of the facial expressions consisted of eight types: (a) laughing/smiling, (b) plain, (c) anxiety, (d) serious, (e) angry, (f) others, (g) multiexpressions, and (h) unknown.

The second sub-measure was the subjects' modes of movement in pictures. Its categories were (a) movement, (b) still, and (c) both.

The third sub-measure was the setting of pictures. Its categories were (a) outside, (b) inside, and (c) unknown.

The fourth sub-measure was the time appearing in pictures. Its categories were (a) morning, (b) afternoon, (c) evening, (d) night, and (e) unknown.

The fifth sub-measure was the relationship between pictures and headlines. 
Pictures and headlines were examined to see whether they were related to one another.

\section{$\underline{\text { Sample Selection }}$}

\section{Defining Corporate Advertising}

The researcher defined several rules of limits for the sample selection in this study. The sample consisted of corporate advertising by for-profit organizations, including foreign-owned companies. In the sample, special-occasion advertisements, such as announcements of mergers and advocacy or investor relations' advertisements, were included. Likewise, different advertisements from the same company in the same issue were considered as independent samples. However, the sample excluded duplication in the same publication.

To distinguish corporate advertisements from company-plus-product hybrid advertisements, corporate advertisements under some conditions were excluded. Advertisements promoting a specific product or service or advertised by more than two companies were excluded. Fashion brand advertising was also excluded because its advertising style was totally different from other industries' corporate advertising.

\section{Sampling Period and Media}

The entire year of 1998 was selected as the sampling period to avoid biased samples resulting from seasonal differences or from fiscal month differences. Four topranking newspapers were chosen: The Wall Street Journal and The New York Times from the United States and Yomiuri and Nikkei from Japan. Corporate advertisements at least a quarter-page for the U.S. papers and one third of a page for the Japanese papers were used. 
With respect to magazine, circulation figures cannot be the only measure of publication selections because of the differences in media structures in these two countries. By considering other comparative factors. such as cycle terms, type of magazine, and the nature of corporate advertising, the weekly news magazine and weekly business magazines were selected. Regarding the news and general interest magazines, Newsweek in the United States was compatible with lewsweek Japan. Business Week in the United States and Nikkei Business in Japan were selected as representatives of weekly business media.

\section{Sampling}

To simplify the sampling process, only advertisements in the main and business sections were examined from U.S. papers. Unlike U.S. papers, Japanese papers have only one section, which includes a few local pages. The advertisements appearing in local pages were excluded because they center on local markets.

Saturday and Sunday editions were excluded because The Wall Street Journal does not have these editions and the Sunday edition of The New York Times has different features from its weekday editions. Likewise, evening editions of the Japanese papers were excluded because the selected U.S. papers do not have evening editions.

To collect 400 corporate advertisements per country, the researcher employed the systematic sampling method. The range was determined by conducting pre-sampling. To obtain 200 advertisements per newspaper, the sample included all advertisements from every eighth day for The Wall Street Journal, every other day for The New York Times and Nikkei, and every day for Yomiuri. 
The systematic sampling method was also employed for the sample of magazine advertisements. To obtain 200 samples per country, the sample included all advertisements from every fifth issue for Business Week, every other issue for Newsweek and Nikkei Business, and every issue for Newsweek Japan.

\section{Description of the Sample}

Altogether 1,208 corporate advertisements appeared in research publications, excluding duplicate advertisements. The sample from the U.S. newspapers was 456 and the sample from the Japanese newspapers was 380 . The sample from the U.S. magazines was 207 and the sample from the Japanese magazines was 165 .

\section{Data Analysis}

\section{Coding and Reliability}

The coding was conducted by the researcher. To avoid coding confusion, the researcher asked for a second opinion from the advisors who were familiar with this subject.

\section{$\underline{\text { Pretest }}$}

A pretest of about $10 \%$ of the usable corporate advertisements was conducted to test the applicability of the research variables and sub-measures. As a result of this pretest, six values for the types of subjects in pictures were added. They were "a group of people," "office," "plants," "instruments," "vehicles or vessels," and "a part of the human body," such as a hand pointing at something. Together with recording sheets, code books for both newspaper and magazine advertisements were prepared (see appendix). 


\section{Reliability}

To examine reliability, a test-retest was conducted after the completion of the analysis. This was conducted by re-analyzing the extracted sample, a random selection of about $10 \%$ of all samples. After the test-retest was completed, a percentage of agreement was calculated. The percentages ranged between $92 \%$ and $100 \%$ in the acceptable range for the different research variables.

Furthermore, a test of reliability by two independent coders was applied to the coding scheme. Another person, who was fluent in both English and Japanese, coded the same extracted sample for the test-retest. The result suggested a minimum of observer error and was within the acceptable range, between $88 \%$ and $97 \%$ for the different research variables.

\section{Hypotheses}

By applying research variables based on the cultural dimensions and semiotic codes for a picture analysis, the researcher proposed these hypotheses $(\underline{H})$.

\section{$\underline{\text { Low-context vs. High-context Cultures }}$}

H1: The number and the portion of visual elements are greater in Japanese corporate advertisements than in U.S. corporate advertisements.

H2: The quantity of data and the portion of copy per advertisement are greater in U.S. corporate advertisements than in Japanese corporate advertisements.

\section{Individualism vs. Collectivism}

H3: Informational content about company leaders or identified employees is seen more in 
U.S. corporate advertisements than in Japanese corporate advertisements.

H4: Informational content about groups or anonymous employees is seen more in Japanese corporate advertisements than in U.S. corporate advertisements.

\section{$\underline{\text { Power Distance }}$}

H5: Informational content about company size and company's network is seen more in Japanese corporate advertisements than in U.S. corporate advertisements.

\section{Uncertainty Avoidance}

H6: Informational content about testing, endorsement by experts, and technology or design breakthroughs is seen more in Japanese corporate advertisements than in U.S. corporate advertisements.

\section{Long-term Orientation}

H7: Informational content about a company's history (the number of years since the company was founded) is seen more in Japanese corporate advertisements than in U.S. corporate advertisements.

\section{Communitarian Values}

H8: Informational content about company's market shares is seen more in Japanese corporate advertisements than in U.S. corporate advertisements.

\section{Signs in Pictures}

H9: The number of icons and indexical signs used in pictures is higher in U.S. corporate advertisements than in Japanese corporate advertisements. 
H10: The number of symbols used in pictures is higher in Japanese corporate advertisements than in U.S. corporate advertisements.

These hypotheses were examined by using the research variables identified earlier. To determine if there were significant differences between these two countries in each research variable, chi-square analyses or $t$-tests were used. An alpha level of .05 was used for all statistical tests.

\section{Generalizability}

Corporate advertising, excluding a company-plus-product hybrid type, constitutes about $1 \%$ of U.S. companies' total advertising expenditure (Rossiter \& Percy, 1997). However, the total number of corporate advertisements in newspapers and magazines is not identified for the year of study. Therefore, the results of this study cannot be generalized from the sample. 


\title{
IV. Findings and Discussions
}

\author{
Findings
}

\section{Overview of Results}

Ten hypotheses examined differences based on cultural influences in the United States and Japan. Five hypotheses were supported or partially supported and five hypotheses were not supported (see Table 2). 
Table 2

Test Results of the Hypotheses

\begin{tabular}{|c|c|c|c|c|c|}
\hline Country & $\begin{array}{l}\text { Hypo } \\
\text { thesis }\end{array}$ & $\begin{array}{c}\text { Cultural } \\
\text { Dimension }\end{array}$ & Research Variables & Type of Test & P-Value \\
\hline Japan & $\underline{\mathrm{Hl}}$ & & The number of visuals & t-test & $\mathrm{p}<.007$ \\
\hline Japan & $\mathrm{H} 1$ & $\begin{array}{l}\text { Low-context } \\
\text { vs. }\end{array}$ & The portion of visuals & chi-square & $\mathrm{p}<.001$ \\
\hline USA & $\underline{\mathrm{H}} 2$ & High-context & The portion of copy & chi-square & $\mathrm{p}<.001$ \\
\hline USA & $\underline{\mathrm{H}} 2$ & Cultures & The quantity of data & $t$-test & NS \\
\hline USA & $\underline{\mathrm{H} 3}$ & $\begin{array}{l}\text { Individualism } \\
\text { vs. } \\
\text { Collectivism }\end{array}$ & Type of spokesperson & chi-square & NS \\
\hline Japan & $\underline{\mathrm{H} 5}$ & Power Distance & Company size & chi-square & $\mathrm{p}<.001$ \\
\hline Japan & H5 & & Company's networks & $t$-test & $\mathrm{p}<.002^{\mathrm{a}}$ \\
\hline Japan & $\underline{\mathrm{H}} 6$ & Uncertainty & Testing & $t$-test & $\mathrm{NS}$ \\
\hline Japan & H6 & Avoidance & Type of endorser & chi-square & $\mathrm{p}<.05^{\mathrm{a}}$ \\
\hline Japan & $\underline{\mathrm{H}} 6$ & & $\begin{array}{c}\text { Technology or design } \\
\text { breakthroughs }\end{array}$ & $t$-test & $\mathrm{p}<.001$ \\
\hline Japan & $\underline{\mathrm{H}} 7$ & $\begin{array}{l}\text { Long-term } \\
\text { Orientation }\end{array}$ & Company's history & chi-square & $\mathrm{p}<.001$ \\
\hline Japan & $\underline{\mathrm{H}} 8$ & $\begin{array}{c}\text { Communitarian } \\
\text { Values }\end{array}$ & $\begin{array}{l}\text { Company's } \\
\text { market shares }\end{array}$ & chi-square & NS \\
\hline $\begin{array}{l}\text { USA } \\
\text { Japan }\end{array}$ & $\begin{array}{l}\text { H9 } \\
\text { H10 }\end{array}$ & Signs & Subjects in pictures & chi-square & NS \\
\hline
\end{tabular}




\section{Low-context vs. High-context Cultures}

\section{Hypothesis $1(\mathrm{H} 1)$}

H1, which the number and the portion of visual elements were greater in Japanese corporate advertisements than in U.S. advertisements, was supported. The mean of visual elements was 2.81 in the U.S. corporate advertisements and 3.97 in the Japanese advertisements. The result from the two-tailed $t$-test reached significance at the .05 level: $t(836)=2.70, p<.007$

Regarding the portion of visual elements. the chi-square indicated that the difference was significant: $\chi^{2}(3, N=833)=43.69, p<.001$ (see Table 3$)$. In the Japanese sample, $60 \%$ of corporate advertisements were more than half filled with visual elements. By contrast, only $42 \%$ of the U.S. sample were more than half filled with visual elements. 
Table 3

Distribution of Corporate Advertisements by the Portion of Visual Elements

\begin{tabular}{|c|c|c|}
\hline \multirow[b]{2}{*}{ No. of Advertisements ${ }^{a}$} & USA & Japan \\
\hline & 454 & 379 \\
\hline & $\%$ of Total & $\%$ of Total \\
\hline $76 \%-100 \%$ & 23 & 37 \\
\hline $51 \%-75 \%$ & 19 & 23 \\
\hline $26 \%-50 \%$ & 24 & 24 \\
\hline $1 \%-25 \%$ & 34 & 16 \\
\hline$\chi^{2}(3 . N=833)=43.69$ & The sampl & $\% "$ categor \\
\hline
\end{tabular}

Hypothesis $2(\mathrm{H} 2)$

The second hypothesis, which the quantity of data and the portion of copy were greater in U.S. corporate advertisements than in Japanese advertisements, was partially supported. With respect to the quantity of data, the result from the two-tailed $t$-test showed that there was no significant difference between these two countries. On the other hand, the chi-square analysis regarding the portion of copy revealed this difference to be significant: $\chi^{2}(3, N=821)=35.64, p<.001$ (see Table 4). In the U.S. sample, $25 \%$ of corporate advertisements in the U.S. sample were more than one quarter filled with copy. By contrast, only $10 \%$ of the advertisements in the Japanese sample were more than one quarter filled with copy. 
Table 4

Distribution of Corporate Advertisements by the Portion of Copy

\begin{tabular}{lcc}
\hline & USA & Japan \\
\cline { 2 - 3 } No. of Advertisements ${ }^{2}$ & 449 & 372 \\
\hline $76 \%-100 \%$ & $\%$ of Total & 1 \\
$51 \%-75 \%$ & 16 & 2 \\
$26 \%-50 \%$ & 75 & 90 \\
$1 \%-25 \%$ & 2 & 7 \\
\hline$\chi^{2}(3, \mathrm{~N}=821)=35.64, \mathrm{p}<.001 .{ }^{\mathrm{a}}$ The sample of the "0\%" category \\
was excluded from the total sample because of its small quantity.
\end{tabular}

\section{Individualism vs. Collectivism}

Hypothesis $3(\mathrm{H} 3)$

The third hypothesis, which the informational content about company leaders or identified employees was seen more in U.S. corporate advertisements than in Japanese corporate advertisements, was not supported. The chi-square was calculated between the total of the "company's leaders" and the "identified employees" categories and the total of the "groups" and the "anonymous" categories. The result from the chi-square showed that there was no significant difference between these countries. It should be noted that the sample of advertisements having spokespersons within organizations was small in 
both countries. Only $6 \%$ of the U.S. corporate advertisements and $10 \%$ of the Japanese corporate advertisements had spokespersons within organizations.

Hypothesis $4(\mathrm{H} 4)$

Likewise, the fourth hypothesis, which the informational content about groups or anonymous employees was seen more in Japanese corporate advertisements than in U.S. corporate advertisements. was not supported. The chi-square. also used for $\underline{\mathrm{H}} 3$, indicated that no significant association existed between these two countries.

Hypothesis $5(\underline{\mathrm{H}} 5)$

\section{Power Distance}

H5, which the informational content about company size and company's networks was seen more in Japanese corporate advertisements than in U.S. corporate advertisements, was partially supported. The chi-square for informational content about company size was found to differ significantly between these two countries: $\chi^{2}(1, N=$ $836)=22.17, p<.001$ (see Table 5). In the Japanese sample, $15 \%$ of corporate advertisements had informational content about company size. On the other hand, the same informational content appeared in only $6 \%$ of the U.S. sample. 
Table 5

Distribution of Corporate Advertisements by Informational Content about Company Size

\begin{tabular}{lcc}
\hline & USA & Japan \\
\cline { 2 - 3 } No. of Advertisements & 456 & 380 \\
\hline Used & \% of Total & \% of Total \\
None & 6 & 15 \\
\hline$\chi^{2}(1, N=836)=22.17, p<.001$. & 94 & 85 \\
\hline
\end{tabular}

In addition, the average numbers of employees or branches appearing in corporate advertisements also differed greatly. The average number of employees in the U.S. sample was 45,137 versus only 23,140 in the Japanese sample. Likewise. the average number of branches in the U.S. sample was 962 versus only 67 in the Japanese sample.

However, the results regarding company's networks were in opposition to predictions. The performed two-tailed $t$-test revealed that there was a significant difference at .05 level: $t(836)=3.12, p<.002$. However, the informational content about company's networks was, in fact, seen more in the United States than in Japan. In the U.S. sample, $17 \%$ of corporate advertisements had informational content about the company's network. This information appeared in only $11 \%$ of the Japanese advertising. 


\section{Uncertainty Avoidance}

Hypothesis $6(\mathrm{H} 6)$

H6, which informational content about testing, endorsement by experts, and technology or design breakthroughs was seen more in Japanese corporate advertisements than in U.S. corporate advertisements, was partially supported. The result from the twotailed $t$-test for informational content about testing showed no significant difference at .05 level.

Furthermore, the result for type of endorser was in opposition to predictions. The chi-square reached significance: $\chi^{2}(1, N=186)=4.65$, $p<.05$. However, the "experts" type of endorser was actually seen more in the U.S. sample than in the Japanese sample.

With respect to the informational content about technology or design breakthroughs, the two-tailed $t$-test indicated that there was a significant difference at the .05 level: $t(836)=-4.17, p<.001$.

Hypothesis 7 (H7)

\section{$\underline{\text { Long-term Orientation }}$}

H7, which informational content about a company's history (the number of years since the company was founded) was seen more in the Japanese corporate advertisements than in U.S. corporate advertisements, was supported: $\chi^{2}(1, N=836)=38.74, p<.001$ (see Table 6). However, the average number of years since the company's foundation in both countries was almost same, 70 years in the United States and 71 years in Japan. 
Table 6

Distribution of Corporate Advertisements by Informational Content about Company's

History

\begin{tabular}{lcc}
\hline & USA & Japan \\
\cline { 2 - 3 } No. of Advertisements & 456 & 380 \\
\hline & \% of Total & \% of Total \\
\hline Used & 7 & 22 \\
None & 93 & 78 \\
\hline$\chi^{2}(1, \mathrm{~N}=836)=38.74, \mathrm{p}<.001$. & &
\end{tabular}

\section{Communitarian Values}

Hypothesis $8(\mathrm{H} 8)$

The last hypothesis in the cultural dimensions was that the informational content about company's market shares was seen more in the Japanese corporate advertisements. The result received from the chi-square analysis did not reach significance. Additionally. the average percentages of market shares in corporate advertisements appeared nearly the same in both samples. They were $55 \%$ in the U.S. sample and $61 \%$ in the Japanese sample.

The informational content about company's market shares appeared in small numbers. Only $4 \%$ of the U.S. corporate advertising and $6 \%$ of the Japanese advertising carried this information. 


\section{Signs in Pictures}

\section{Hypothesis $9(\mathrm{H} 9)$}

H9, which the number of icons and indexical signs in pictures was higher in U.S. corporate advertisements than in Japanese advertisements. was not supported. The chisquare showed the result of no significant difference between these two countries.

\section{Hypothesis $10(\mathrm{H} 10)$}

H10, which the number of symbols used in pictures was higher in Japanese corporate advertisements than in U.S. advertisements, was also not supported based on the same chi-square performed for $\underline{H} 9$. 


\section{Discussion}

\section{Implications of Result}

It was important to analyze why some hypotheses were not supported, and it was necessary to look for a logical connection between supported and unsupported hypotheses.

Half of the hypotheses predicting more content in Japanese advertisements and only one quarter of the hypotheses predicting more content in U.S. advertisements were supported. However, it cannot be proved that cultural influences were more apparent in the Japanese corporate advertisements. Although more hypotheses were supported concerning Japan than concerning the United States, of the total ratio, only half of the hypotheses were supported.

With respect to cultural dimensions, the hypothesis in the "long-term orientations" dimension and most of the hypotheses in the "high-context vs. low-context cultures" dimension were supported. On the other hand, none of the hypotheses regarding the "individualism vs. collectivism" and the "communitarian values" cultural dimensions were supported.

In the "high-context vs. low-context" cultural dimension, the result from the informational content about data did not support the hypothesis. At least one interpretation might explain the reasons.

Corporate advertisements may not need company data as much as product advertisements do. In general, data are used to sell products as a persuasive communication technique in U.S. advertisements (Mooij, 1997). However, for corporate 
advertising, particularly for the purpose of corporate branding, data may not be a necessary part of persuasive communication techniques. Or, this type of communication technique may be different in product advertising than it is in corporate advertising.

In the "individualism vs. collectivism" cultural dimension, the two hypotheses failed to provide satisfactory results. The possible reason was that both hypotheses referred to type of spokesperson. The number of advertisements having this information was only 25 in the United States and 38 in Japan. Considering these small numbers, these research variables were probably inappropriate to an examination of corporate advertising.

In the "power distance" cultural dimension, the result showed that Japanese corporate advertisements had more informational content about company size than U.S. corporate advertisements, as predicted.

However, the result regarding the informational content about company"s networks did not support the hypothesis. One reason for this result may be that it is not necessary to advertise company networks in Japan. Existing company networks such as Keiretsu have been historically integrated into Japanese society so that most of the public would know about them. Unlike most Japanese companies, U.S. companies networks generally have been tied up for financial or strategic alliance reasons. Consequently, many U.S. companies would need to inform the public about them.

In the "uncertainty avoidance" cultural dimension, only one out of three hypotheses was supported. As predicted in $\underline{\mathrm{H}}$, the information content about technology or design breakthroughs was seen more in Japan. However, other parts of this hypothesis 
were not supported. The result for the informational content about testing showed a nonsignificant difference between these two countries.

Furthermore, the result for type of endorser in corporate advertisements was opposite to the predictions. The use of experts as endorsers was hypothesized to appear more in Japanese corporate advertisements. However, the use of experts was actually seen more in the U.S. corporate advertisements. Again, a possible explanation could be that the number of corporate advertisements having endorsers was very small. The number of samples having this information was 107 in the United States and 79 in Japan. This suggests that this research variable was not appropriate for the research of corporate advertising.

Another possible reason was that "high-profiled" endorsers were used relatively often in Japan. The percentage of this type in the sample was $47 \%$, which was rather high compared with 5\% in the U.S. sample (see Table 7). This tendency matched another characteristics for collectivistic culture countries. People from these countries are fond of high-profiled persons in their advertisements (Mooij, 1997). In fact, the literature has suggested that using celebrities is one of the most popular forms of advertisement in Japan. This tendency of collectivistic cultures may be stronger than the characteristics of the uncertainty avoidance culture. 
Table 7

Distribution of Corporate Advertisements by Type of Endorser

\begin{tabular}{lcc}
\hline & USA & Japan \\
\cline { 2 - 3 } No. of Advertisements ${ }^{\mathrm{a}}$ & 107 & 79 \\
\hline & \% of Total & \% of Total \\
\hline Experts & 19 & 8 \\
High-profiled & 5 & 47 \\
Clients & 76 & 36 \\
Other & 0 & 9 \\
\hline$\chi^{2}(3, \mathrm{~N}=186)=61.40, \mathrm{p}<.001 . \chi^{2}(1, \mathrm{~N}=186)=4.65, \mathrm{p}<.05$
\end{tabular}

was calculated between the "experts" category and the total of others.

"The sample of the "none" category was excluded from the total sample.

Likewise, there was another trait for type of endorser in the U.S. sample. The rate of the "clients" category as endorsers was $76 \%$, which was very high compared with $37 \%$ in the Japanese sample. The use of "client" endorsers may represent the need for credibility in the United States. Generally, endorsements in low-context cultures are required to have credibility (Mooij, 1997). On the other hand, credibility is a less significant requirement for Asian cultures.

In the "long-term orientations" cultural dimension, informational content about company history appeared in the Japanese corporate advertisements almost three times as 
often as in the U.S. advertisements. Additionally, the researcher noticed that some Japanese companies even make logotypes that show the age of the company. In the Japanese sample, approximately $6 \%$ of newspaper advertisements and $4 \%$ of magazine advertisements had these logotypes. However, none of the U.S advertisements had these logotypes. This was interesting because it demonstrated how these two countries show this information differently. That is, Japanese companies took a visual approach by making the logotypes, whereas U.S. companies took a verbal approach by using words.

The hypothesis that dealt with the "communitarian values" cultural dimension was not confirmed. No significant association existed in the informational content about company's market shares. In addition to the small number of corporate advertisements with this information, this result may be related to the small use of data in corporate advertising overall. The use of data hardly appeared in corporate advertisements. The means for the use of data were 1.01 in the U.S. sample and 0.93 in the Japanese sample. Moreover, this information may not be utilized often because the Japanese prefer to take an indirect communication style as defined in the "high-context vs. low-context cultures" dimension. The informational content about company's market shares could cause conflicts with competitors. That is, this information may be too offensive because it demonstrates the company's own superiority over its competitors.

Turning to the visual analysis, the result of $\underline{\mathrm{H}} 9$ and $\underline{\mathrm{H}} 10$ indicated that signs of subjects in pictures were not significantly different between the United States and Japan. The researcher hypothesized that iconic and indexical subjects in pictures would be used more in the United States and that symbolic subjects would appear more in Japan. If 
anything, iconic subjects in pictures were seen more in Japan than in the United States.

However, it should be noted that the same advertisement for the same company was frequently found in both countries, particularly in the sample of magazines. Although no data were available, the use of standardized advertising seemed to be widespread in both countries. This may be another reason why the type of subjects in pictures did not differ greatly.

\section{Additional Findings}

In addition to examining the hypotheses, the researcher also investigated other traits in terms of the difference between the United States and Japan in corporate advertising.

Regarding type of spokesperson, there were not significant differences between the total of "company"s leaders" and "identified employees" and the total of "groups" and "anonymous employees." However, the "group" in the United States presented a striking contrast to the same category in Japan. In the Japanese sample, $14 \%$ of the companies used groups, whereas the U.S. companies did not use groups as their spokespersons in their advertisements (see Table 8). This may demonstrate the difference between U.S. individualism and Japanese collectivism. 
Table 8

Distribution of Corporate Advertisements by Type of Spokesperson

\begin{tabular}{lcc}
\hline & USA & Japan \\
\cline { 2 - 3 } No. of Adrertisements & 25 & 38 \\
\hline & \% of Total & \% of Total \\
\hline Company"s leaders & 58 & 51 \\
Identified employees & 38 & 30 \\
Groups & 0 & 14 \\
Anonymous employees & 4 & 5 \\
\hline$\chi^{2}(3, N=61)=3.69, \mathrm{p}<.30 .{ }^{2}$ The sample of the "other," "unknown," \\
and "none" categories was excluded from the total sample.
\end{tabular}

Regarding the breakdown by type of business, only informational content about company size indicated significant differences for both the United States and Japan. The data for both countries showed that companies dealing with high-involvement services tended to use informational content about company size. This is quite understandable, considering the characteristics of this business type. Services are "the application of human and mechanical efforts to people or objects to provide intangible benefits to customers" (Pride \& Ferrell, 1997, p. 4). That is, companies that deal with highinvolvement services need to assure consumers even though they have no tangible product to show. The informational content about company size, if it is large, can be one of the elements by which consumers evaluate a company. 
The visual analysis using semiotic codes showed that the use of signs of subjects in pictures was not significantly different in the United States and Japan (see Table 9).

Table 9

Distribution of Corporate Advertisements by Signs: Subjects in Pictures

\begin{tabular}{lcc}
\hline & USA & Japan \\
\cline { 2 - 3 } No. of Advertisements & 207 & 165 \\
\hline Icons & \% of Total & \% of Total \\
Indexes & 15 & 24 \\
Symbols & 36 & 29 \\
\hline$\chi^{2}(2, N=372)=5.70, p<.10$. & 49 & 47 \\
\hline
\end{tabular}

However, some data regarding the type of subjects in pictures showed some differences between the two countries. As stated earlier, the researcher looked at the breakdowns by iconic, indexical, and symbolic subjects in pictures. In these categories, iconic and indexical subjects would be influenced by the character of the companies. If so, only symbolic subjects in pictures could stand for cultural values.

Analysis of the types of symbolic subjects in pictures showed some differences between the two countries (see Table 10). In addition, by looking at differences in the symbolic subjects (the signifier), the researcher further analyzed the connotations (the signified). 
Table 10

Distribution of Corporate Advertisements by Symbolic Subjects in Pictures (sorted by U.S. rank order)

\begin{tabular}{lcc}
\hline & USA & Japan \\
\cline { 2 - 3 } No. of Advertisements & 102 & 78 \\
\hline & $\%$ of Total & $\%$ of Total \\
\hline Adults & 69 & 50
\end{tabular}

A group of people

Children

12

13

Nature and plants

10

9

A part of the human body

6

9

Animals

5

12

Building

5

9

Families

3

4

Other

28

15

The categories of "foods," "the elderly," "machinery," "instruments,"

"offices," "vehicles and vessels," and "special characters" were combined with the "other" category because of their small quantity. The "nature" and "plants" categories were combined into one category.

Above all, the use of people as subjects in corporate advertising showed 
differences between the United States and Japan. Adults were used in $69 \%$ of the U.S. corporate advertisements. greatly higher than the $50 \%$ rate of Japanese corporate advertisements. Furthermore, the total use of people in pictures was $95 \%$ in the U.S. sample and $81 \%$ in the Japanese sample ("a part of the human body" was excluded). To present positive images to the public, U.S. companies were more likely to use people in their corporate advertising. This harmonizes with one of the U.S. cultural characteristics, in which appeal is based on individual characters. Moreover, it may indicate that the most important company equity in U.S. companies is people.

By contrast, children, nature and plants, animals, buildings, and a part of the human body were found more in Japan. Applying the concept of "signifier" and "signified," most of these subjects would imply the indirect communication style in Japan. In general, children, nature and plants, and animals would help to portray pleasant concepts like "peace" or "friendship." But these subjects are usually not the company's direct assets or attributions. Likewise, a part of the human body would be used just as a sign rather than as a human being. For example, "clenched fists" would stand for "a strong will" or "anger."

In addition, the data from non-creature types of subjects showed interesting distinctions between these two countries. U.S. companies used machinery, offices, and vehicles or vessels, Japanese companies did not adopt these subjects at all. Instead, the Japanese companies preferred to use buildings more often than the U.S. companies. This may indicate a difference of values between the countries. Although they have a number of connotations, machinery, offices, and vehicles or vessels could be translated as 
"intelligence" or "high technology." That is, these are important values for many Americans. In Japan. the value is more materialistic. Buildings would represent "physical assets." Furthermore, some people may view it further as a success symbol or a symbol of fortune because in a small island country like Japan, real estate is extremely valuable.

Regarding the number of people appearing in corporate advertisements, the chisquare did not indicate a significant difference between the United States and Japan. However, there was an interesting trait in the Japanese sample. Groups of ten or more people appeared in advertisements in the Japanese sample at a rate six times as high as in the U.S. sample. This also demonstrated one of the Japanese cultural characteristics, collectivism.

The data from the relationship between pictures and headlines showed one of the cultural aspects of the two countries. The chi-square examined whether pictures and headlines were related to one another, indicating that the two countries were significantly different: $\chi^{2}(1, N=180)=5.42, p<.02$ (see Table 11). In the U.S. sample, $60 \%$ of the pictures were somewhat related to the headlines in corporate advertisements. The Japanese counterpart was $42 \%$. 
Table 11

Distribution of Corporate Advertisements by the Relationship between Pictures and Headlines

\begin{tabular}{lcc}
\hline & USA & Japan \\
\cline { 2 - 3 } No. of Advertisements & 102 & 78 \\
\hline & \% of Total & \% of Total \\
\hline Yes & 60 & 42 \\
No & 40 & 58 \\
\hline$\chi^{2}(1, N=180)=5.42 . p<.02$. & &
\end{tabular}

Other research sub-measures about symbolic subjects in pictures did not show significant differences between the United States and Japan. These sub-measures included the number of males and females, facial expressions, modes of movements, setting of locations, and the time. In other words, these aspects may be similar in the two countries in terms of the use of symbols in corporate advertising.

Furthermore, business types were more likely to affect the use of symbolic subjects in pictures in Japan. The chi-square examined the relationship between business types and signs in pictures, indicating that there was a significant difference: $\chi^{2}(14, N=$ $165)=39.92, \mathrm{p}<.001$. Above all, companies dealing with high-involvement consumer services were identified, as they tended to use symbolic subjects. 


\section{Summary and Conclusion}

\section{Summary}

\section{Overview of the Study}

The purpose of this study was to identify differences between the United States and Japan in corporate advertising as it relates to corporate branding. It asked the question, "What differences are there between U.S. and Japanese companies concerning their use of corporate advertising for corporate branding purposes?"

To answer this question, the researcher first identified cultural influences, which could be significantly different in the two countries. In the next step, research variables for each country were defined based on cultural dimensions and semiotics. Content analysis of corporate advertising was employed as the research method. Through the analysis, the researcher examined 10 hypotheses using the research variables. As a result, five hypotheses were supported or partially supported and five hypotheses were not supported.

\section{Main Findings}

First, the use of visual elements and copy in corporate advertising was significantly different in the two countries. Visual elements in the Japanese corporate advertisements were considerably significant in terms of both number and portion. By contrast, the U.S. corporate advertisements utilized copy more than the Japanese corporate advertisements did. Although previous research has produced similar findings with regard to product advertising, this study found that these tendencies also apply to 
corporate advertising.

Second, some informational content that appeared more frequently in Japanese corporate advertisements were identified. These were informational content about a company's history (the number of years since the company was established), company size. and technology or design breakthroughs.

Lastly, the types of symbolic subjects in pictures appeared to be different in corporate advertising in the two countries. The use of people was seen more in U.S. corporate advertisements. However, the use of large numbers of people appeared more in Japanese corporate advertisements. The use of animals, buildings, nature and plants, and a part of the human body were present more in Japanese corporate advertisements than in U.S. corporate advertisements.

\section{Conclusion}

This study showed that cultural influences appeared randomly in corporate advertising for corporate branding purposes. Although it is impossible to generalize any finding of this study, these findings give at least some guidance to those producing advertisements for corporate branding in the United States and Japan. On the basis of the discussions in this study, two major conclusions can be drawn.

\section{Conclusions}

The first conclusion that this study suggests is that some differences based on cultural characteristics exist between corporate branding in the United States and in Japan. Furthermore, this study suggests that the information about corporate equity, as depicted 
in corporate advertising, greatly differs between the United States and Japan. and that these differences are related to cultural influences. As long as these differences exist, understanding them will allow U.S. and Japanese companies to know how to best express their corporate identity as brands.

The second conclusion is about methodology for cross-cultural advertising research. As seen in this study, many standardized corporate advertisements for global use have appeared recently. Most of the advertisements were translated as appropriate. but the contents and visuals of the advertisements remained the same. Hence. these standardized advertisements would only reflect national values when used where the headquarters are located. To identify the differences among countries, these standardized advertisements should be excluded.

\section{Contribution to Theory and Practice}

This study suggested another possibility for the modes for cross-cultural advertising research. Most cross-cultural advertising research has employed existing research variables and applied them to cultural dimensions. However, this study tried to utilize several research variables extracted from cultural dimensions. It was a meaningful trial in terms of how cuitural theories worked on actual business practices.

In addition, this study contributed to the research on corporate advertising. The research on corporate advertising has been relatively small compared with research on product advertising. This study focused on corporate advertising because this communication activity is one of the key strategies in terms of corporate branding.

In business practices, the informational content identified in this study for both 
countries can be used in other communication activities for the purpose of corporate branding. At the same time, this study also showed that business practitioners in both countries should be sensitive to the possibility of cultural differences. Nevertheless, Roth (1995) found that marketing managers seem to be using fewer market indicators to develop and implement their brand image strategies than previous cross-cultural studies have recommended.

Similarly, the use of standardized advertisements should be used carefully. Standardized advertisements should be examined to determine whether they really work with only language translation in the international markets. For example, it is possible to perform minor changes by adding more appropriate information or removing unnecessary information.

\section{$\underline{\text { Limitations of Research }}$}

Admittedly, this study had limitations, as noted earlier. This was a study to investigate cultural differences between the United States and Japan appearing in corporate advertisements. However, to understand the entire activity of corporate branding, many other factors should have been examined.

This study also had some limitations as research on corporate advertising. First, the four newspapers and four magazines sampled do not represent all vehicles for corporate advertising in both countries. Other print and broadcast media, which are also utilized for the purpose of corporate advertising, could be examined.

Furthermore, there may be certain biases in this study due to the researcher's background, as a native of Japan. Mooij (1997) pointed out that most cross-cultural 
advertising studies had ethnocentrism in assumptions, hypotheses, and methods.

\section{$\underline{\text { Direction for Future Research }}$}

This study examined one of the communication activities in corporate branding in the United States and Japan. However, it is possible to examine other communication activities, other countries, and other influences from macro- to micro-levels.

Moreover, further research combining other research methods would be meaningful. For example. case studies of individual companies in both countries would provide a deeper understanding of corporate branding. It could explore other communication activities such as public relations, marketing communication, personal selling, or organizational cultures in terms of corporate branding among countries.

In addition, similar studies can be conducted to examine whether cultural influences will change over time. As of today, the Japanese economy has been struggling through severe recession since 1991. This recession certainly has affected business practices, management styles, and public minds. As described in Theory $Z$ (Ouchi, 1981), Japanese organizations were previously characterized by lifetime employment, slow advancement, informal control, consensus decision making, and generalized career paths. Much literature has suggested that these characteristics have been created by the influence from the Japanese national culture. However, these systems in Japanese organizations have been collapsing rapidly because of this recession. This may mean that the influence of the economy could overcome cultural influences. 


\section{References}

Aaker, David A. (1991). Managing brand equity. New York: The Free Press.

Abecasis-Phillips, John A. S. (1994). Doing business with the Japanese. Chicago: NTC Publishing Group.

Albers-Miller, Nancy D., \& Gelb, Betsy D. (1996). Business advertising appeals as a mirror of cultural dimensions: A study of eleven countries. Journal of Advertising, 25(4), 57-70.

Alden, Dana L.. \& Martin, Drew (1995). Global and cultural characteristics of humor in advertising: The case of Japan. Journal of Global Marketing, 9(1/2), 121-142.

Babbie, Earl (1998). The practice of social research ( $8^{\text {th }}$ ed.). Belmont, CA: Wadsworth Publishing Company.

Berger, Arthur Asa (1995). Cultural criticism: A primer of key concepts. Thousand Oaks, CA: Sage.

Berger, Arthur Asa (1998). Media analysis techniques. Thousand Oaks. CA: Sage.

Burnett, John, \& Moriarty, Sandra (1998). Introduction to marketing communication: An integrated approach. Upper Saddle River, NJ: Prentice-Hall.

Cassino, Kip D. (1997). A world of advertising. American Demographics, 19(11) November, 57-60.

Di Benedetto, Anthony C.; Tamate, Mariko; \& Chandran, Rajan (1992). Developing creative advertising strategy for the Japanese marketplace. Journal of Advertising Research, 32(1), 39-48.

Dozier, David M.; Grunig, Larissa A.; \& Grunig, James E. (1995). Manager's guide to excellence in public relations and communication management. Mahwah. $\mathrm{NJ}$ : Lawrence Erlbaum Associates.

Elazar, Daniel J. (1994). The American mosaic: The impact of space, time, and culture on American politics. Boulder, $\mathrm{CO}$ : Westview Press.

Genther, Phyllis A. (1990). A history of Japan's government-business relationship: The passenger car industry. Ann Arbor, MI: The University of Michigan Press. 
Gregory. James R. (1997). Leverage the corporate brand. Chicago:

NTC/Contemporary Publishing Company.

Griffin. Tom (1993). International marketing communications. Oxford, England: Butterworth-Heinemann.

Griffin, Tom; McArthur, David; Yamaki, Toshio: \& Hidalgo, Pedro (1998). The A. B. Cs of advertising management: Perceptions and practices of managers in Chile. Japan \& the United States. International Journal of Advertising, 17(2), 169-1 87.

Hall, Edward T., \& Hall, Mildred R. (1987). Hidden differences. New York: Anchor Press/Doubleday \& Company.

Hall, Edward T., \& Hall, Mildred R. (1991). Understanding cultural differences. Yarmouth, ME: Intercultural Press.

Halliday, Jean (1998, April 6). Brand management builds on image making. Advertising Age, pp. s2-s24.

Hampden-Turner, Charles, \& Trompenaars, Alfons (1993). The seven cultures of capitalism. New York: Bantam Doubleday Dell Publishing Group.

Han, Jin K., \& Schmitt, Bernd H. (1997). Product-category dynamics and corporate identity in brand extensions: A comparison of Hong Kong and U.S. Consumers. Journal of International Marketing, 5(1), 77-92.

Handy facts on U.S. - Japan economic relations. (1998). Tokyo: Japan External Trade Organization.

Harvey, Michael G. (1993). Point of view: A model to determine standardization of the advertising process in international markets. Journal of Advertising Research, $33(4), 57-64$.

Hendry, Joy (1995). Understanding Japanese society (2nd ed.). New York: Routledge.

Hofstede, Greet H. (1984a, January). Cultural dimensions in management and planning. Asia Pacific Journal of Management, 1(2), 81-99.

Hofstede, Greet H. (1984b). Culture's consequences, international differences in workrelated values. Beverly Hills, CA: Sage.

Hofstede, Greet H. (1991). Cultures and organization: Software of the mind. New York: McGraw-Hill. 
Ishizawa, Yasuji (1996). Nichibei kankei to mass media [U.S.- Japan relations and mass media]. Tokyo: Maruzen.

Kanso, Ali (1992). International advertising strategies: Global commitment to local vision. Journal of Advertising Research, 32(1), 10-14.

Kobayashi. Sadao (1998). Senryaku koukoku no jidai [Strategic advertising]. Tokyo: Nihonkeizai shinbunsha.

Koranteng, Juliana (1998, May 11). Top global ad markets. Advertising Age International. 15-19.

Kotabe, Masaaki, \& Wheiler, Kent W. (1996). Anticompetitive practice in Japan. Westport. CT: Praeger.

Koukoku hakusho 1997 [The advertising white paper]. (1997). Tokyo: Nihon keizai shinbunsha.

Leong, Siew Meng; Ang, Swee Hoon; \& Tham, Lai Leng (1996). Increasing brand name recall in print advertising among Asian consumers. Journal of Advertising, 25(2), $65-81$.

Lin, Carolyn A. (1993). Cultural differences in message strategies: A comparison between American and Japanese TV commercials. Journal of Advertising Research, 33(July/August), 40-48.

Lin, Carolyn A., \& Salwen, Michael B. (1995). Product information strategies of American and Japanese television advertisements. International Journal of Advertising, I $+(1)$, 55-unknown.

McLeod, Douglas M., \& Kunita, Makoto (1994). A comparative analysis of the use of corporate advertising in the United States and Japan International Journal of Advertising, 13(2), 137-152.

McQuail, Denis (1994). Mass communication theory: An introduction (3rd ed.). London: Sage.

Miracle, Gordon E.; Taylor, Charles R.; \& Chang, Kyu Yeol. (1992). Culture and advertising executions: A comparison of selected characteristics of Japanese and U.S. television commercials. Journal of International Consumer Marketing, $4(4)$, 89-113.

Mooij, Marieke K. de (1997). Global marketing and advertising: Understanding cultural paradoxes. Thousand Oaks, CA: Sage. 
Morgan, James C., \& Morgan, Jefrey J. (1991). Cracking Japanese market: Strategies for success in the new global economy. New York: The Free Press.

Mueller. Barbara (1992). Standardization vs. specialization: An examination of Westernization in Japanese advertising. Journal of Advertising Research, 32(1). $15-19$.

Negandhi, Anant R. (1983). Cross-cultural management research: Trend and future directions. Journal of International Business Studies, If(Fall), 17-28.

Noth, Winfried (1990). Handbook of semiotics. Bloomington and Indianapolis, IN: Indiana University Press.

Oblas, Peter B. (1995). Perspectives on race and culture in Japanese society: The mass media and ethnicity. New York: The Edwin Mellen Press.

Ouchi, William G. (1981). Theory Z. New York: Avon Books.

Pierce, John R. (1962). Symbols, signals, and noise. London: Hutchinson.

Pride, William M., \& Ferrell, O. C. (1997). Marketing (10 ${ }^{\text {th }}$ ed.). Boston: Houghton Mifflin Company.

Ramaprasad, Jyotika, \& Hasegawa, Kazuyo (1992). Creative strategies in American and Japanese TV commercials: A comparison. Journal of Advertising Research, $32(1), 59-67$.

Rice, Chris. (1993). Consumer behavior: Behavioral aspects of marketing. Oxford, England: Butterworth-Heinemann.

Rossiter, John R., \& Percy, Larry (1997). Advertising communications and promotion management. New York: McGraw-Hill.

Roth, Martin S. (1995). Effects of global conditions on brand image customization and brand performance. Journal of Advertising, 24(4), 55-76.

Sakakibara, Eisuke (1993). Beyond capitalism: The Japanese model of market economies. Lanham, MD: University Press of America.

Saussure, F. de (1960). Course in general linguistics. London: Peter Owen. (Original work published 1915)

Saussure, F. de (1966). A course in general linguistics. New York: McGraw-Hill. 
Schmitt. Bernd H., \& Pan, Young (1994). Managing corporate and brand identities in the Asia-Pacific region. California .Management Review, 36(4), 32-48.

Schmitt, Bernd H., \& Simonson, Alexander (1997). Marketing aesthetics: The strategic management of brands, identity: and image. New York: The Free Press.

Schultz, Don E., Tannenbaum, Stanley I.. \& Lauterborn. Robert F. (1993). Integrated marketing communications. Chicago: NTC Publishing Group.

Sengupta, Subir (1995). The influence of culture on portrayals of women in television commercials: A comparison between the United States and Japan. International Journal of Advertising, IH(4), 315-333.

Shoemaker, Pamela J., \& Reese, Stephen D. (1996). Mediating the message: Theories of influences on mass media content (2nd ed.). White Plains, NY: Longman.

Shuter, Robert (1989). The international marketplace. In Molefi K. Asante \& William B. Gudykunst (Eds.), Handbook of international and intercultural communication (pp. 392-406). Newbury Park, CA: Sage.

Stevenson, Robert L. (1994). Global communication in the twenty-first century. White Plains, NY: Longman.

Tse, D. K.; Belk R. W.; \& Zhou, N. (1989). Becoming a consumer society: A longitudinal and cross-cultural content analysis of print ads from Hong Kong, the People's Republic of China and Taiwan. Journal of Consumer Research. 15(3) March, 457-472.

Washington, Frank S. (1997, January 6). Japanese adopt 'image' ad strategy. Automotive-News, p. 8.

Wilks, Stephen, \& Wright, Maurice (1991). The comparative context of Japanese political economy. In Stephen Wilks \& Maurice Wright, Maurice (Eds.), The promotion and regulation of industry in Japan (pp. 11-48). New York: St. Martin's Press.

Wilson, Clint C., \& Gutierrez, Felix (1995). Race, multiculturalism, and the media: From mass to class communication. Thousand Oaks, CA: Sage. 


\section{Appendix}

\section{Code Book 1: For the Informational Content Analysis}

Research variables

\begin{tabular}{|c|c|c|c|c|}
\hline $\begin{array}{c}\text { Cultural } \\
\text { Dimensions }\end{array}$ & Variables & Descriptions & Codes & Categories \\
\hline \multirow{12}{*}{$\begin{array}{l}\text { High-context } \\
\text { vs. } \\
\text { Low-context }\end{array}$} & \multirow[t]{5}{*}{$\overline{\mathrm{VI}}$} & \multirow[t]{5}{*}{ The portion of copy } & $\overline{\bar{l}}$ & $0 \%$ \\
\hline & & & 2 & $1 \%-25 \%$ \\
\hline & & & 3 & $26 \%-50 \%$ \\
\hline & & & 4 & $51 \%-75 \%$ \\
\hline & & & 5 & $76 \%-100 \%$ \\
\hline & $\mathrm{V} 2$ & The number of data & Quantity & \\
\hline & V3 & $\begin{array}{l}\text { The number of } \\
\text { visuals }\end{array}$ & Quantity & \\
\hline & \multirow[t]{5}{*}{ V4 } & \multirow[t]{5}{*}{ The portion of visuals } & 1 & $0 \%$ \\
\hline & & & 2 & $1 \%-25 \%$ \\
\hline & & & 3 & $26 \%-50 \%$ \\
\hline & & & 4 & $51 \%-75 \%$ \\
\hline & & & 5 & $76 \%-100 \%$ \\
\hline
\end{tabular}




\begin{tabular}{|c|c|c|c|c|}
\hline \multirow[b]{2}{*}{ Individualism } & \multirow[t]{7}{*}{$\overline{V 5}$} & \multirow{7}{*}{$\begin{array}{c}\text { Type of } \\
\text { spokesperson }\end{array}$} & 1 & Company leaders \\
\hline & & & 2 & Identified employees \\
\hline vs. & & & 3 & Groups \\
\hline \multirow[t]{4}{*}{ Collectivism } & & & 4 & Anonymous employees \\
\hline & & & 5 & Other \\
\hline & & & 6 & Unknown \\
\hline & & & 7 & None \\
\hline \multirow{3}{*}{ Power Distance } & \multirow[t]{2}{*}{ V6 } & \multirow[t]{2}{*}{ Company size } & 1 & Yes \\
\hline & & & 2 & No \\
\hline & V7 & Company's networks & Quantity & \\
\hline \multirow{8}{*}{ Uncertainty } & $\overline{\mathrm{V} 8}$ & Testing & Quantity & \\
\hline & \multirow[t]{6}{*}{ V9 } & \multirow{6}{*}{$\begin{array}{l}\text { Type of } \\
\text { endorser }\end{array}$} & $\mathrm{I}$ & Experts \\
\hline & & & 2 & High-profiled \\
\hline & & & 3 & Clients \\
\hline & & & 4 & Other \\
\hline & & & 5 & Unknown \\
\hline & & & 6 & None \\
\hline & $\mathrm{V} 10$ & $\begin{array}{c}\text { Technology or } \\
\text { design breakthroughs }\end{array}$ & Quantity & \\
\hline
\end{tabular}




\begin{tabular}{|c|c|c|c|c|}
\hline Long-term & \multirow[t]{2}{*}{ V11 } & \multirow[t]{2}{*}{ Company s history } & 1 & Used \\
\hline Orientations & & & 2 & None \\
\hline \multirow{2}{*}{$\begin{array}{c}\text { Communitarian } \\
\text { Values }\end{array}$} & \multirow[t]{2}{*}{ V12 } & \multirow{2}{*}{$\begin{array}{l}\text { Company's } \\
\text { market shares }\end{array}$} & 1 & Used \\
\hline & & & 2 & None \\
\hline
\end{tabular}

Sub-measure: Business Types

\begin{tabular}{|c|l|}
\hline SM1 & Type \\
\hline \hline 1 & Manufacturers of low-involvement consumer products \\
\hline 2 & Manufacturers of high-involvement consumer products \\
\hline 3 & Manufacturers of industrial products \\
\hline 4 & Distributors/Retailers \\
\hline 5 & Low-involvement Services \\
\hline 6 & High-involvement Services \\
\hline 7 & Business to Business Services \\
\hline 8 & Other \\
\hline 9 & Unknown \\
\hline
\end{tabular}




\section{Code Book 2: For the Visual Analysis}

Signs

\begin{tabular}{|c|c|c|}
\hline Variables & Codes & Categories \\
\hline \hline V1 & 1 & Icons \\
& 2 & Indexes \\
\cline { 2 - 3 } & 3 & Symbols \\
\cline { 2 - 3 } & & \\
\hline
\end{tabular}

$\underline{\text { Sub-measures }}$

\begin{tabular}{|c|c|c|c|}
\hline SV & Description & Code & $\overline{\text { Category }}$ \\
\hline \multirow[t]{10}{*}{$\overline{\text { SVI }}$} & \multirow{10}{*}{$\begin{array}{c}\text { Type } \\
\text { of } \\
\text { subjects }\end{array}$} & $\overline{\overline{1}}$ & Families \\
\hline & & 2 & Children \\
\hline & & 3 & Adults \\
\hline & & 4 & The elderly \\
\hline & & 5 & A group of people \\
\hline & & 6 & Animals \\
\hline & & 7 & Buildings \\
\hline & & 8 & Office \\
\hline & & 9 & Nature \\
\hline & & 10 & Plants \\
\hline
\end{tabular}




\begin{tabular}{|c|c|c|c|}
\hline & & 11 & Foods \\
\hline & & 12 & Instruments \\
\hline & & 13 & Machinery \\
\hline & & 14 & Vehicles or Vessels \\
\hline & & 15 & $\begin{array}{c}\text { A part of the human } \\
\text { body }\end{array}$ \\
\hline & & 16 & Special characters \\
\hline & & 17 & Other \\
\hline SV1-A & The number & 1 & 0 \\
\hline & of & 2 & 1 \\
\hline & people & 3 & $2-4$ \\
\hline & & 4 & $5-9$ \\
\hline & & 5 & 10 \\
\hline SVI-B & The number of males & Quantity & \\
\hline SV1-C & The number of females & Quantity & \\
\hline SV1-D & Facial & 1 & Laughing/Smiling \\
\hline & expressions & 2 & Plain \\
\hline & & 3 & Anxiety \\
\hline & & 4 & Serious \\
\hline & & 5 & Angry \\
\hline
\end{tabular}




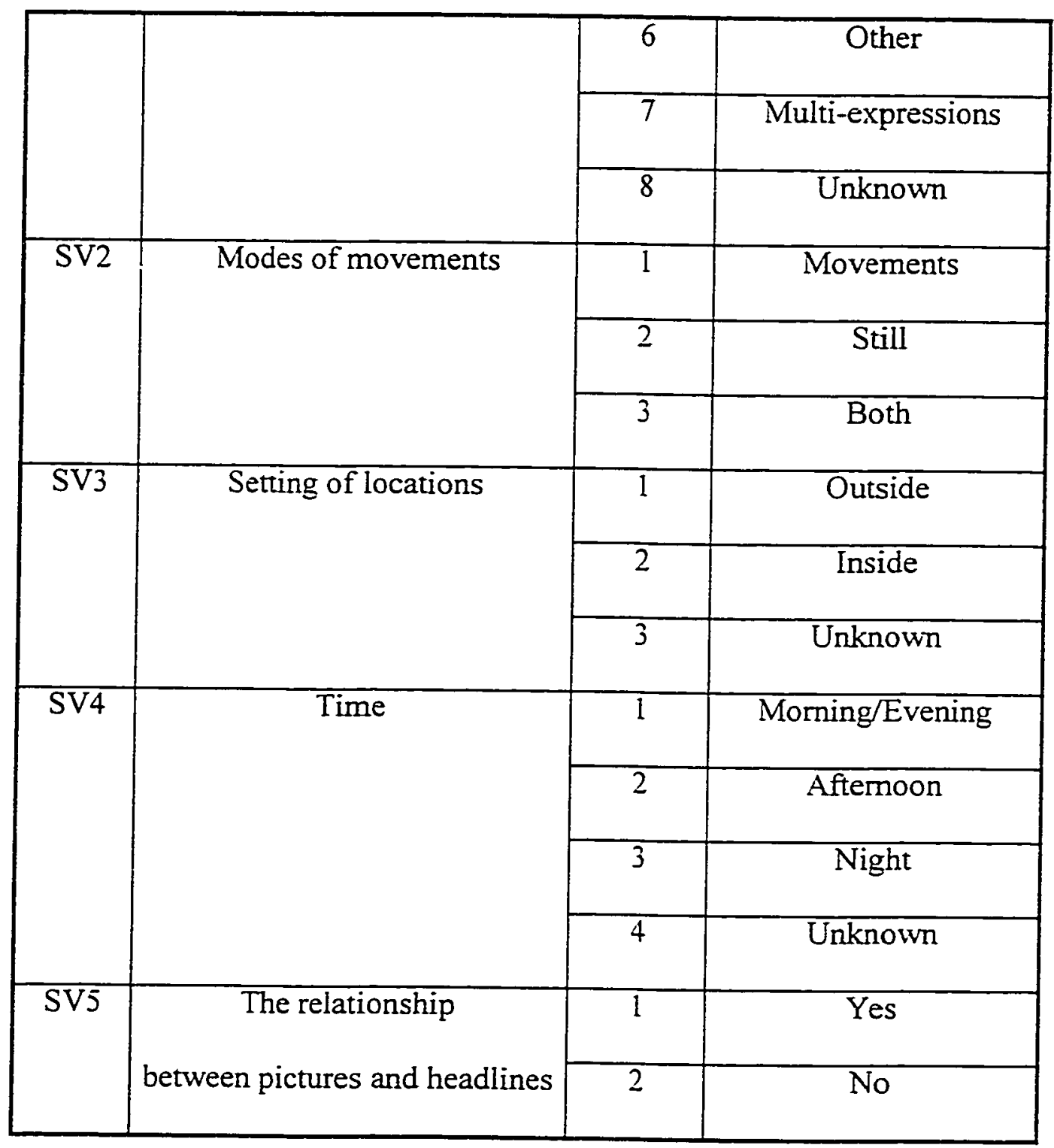


IMAGE EVALUATION
TEST TARGET (QA-3)
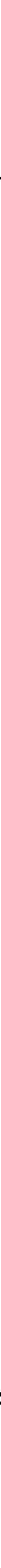